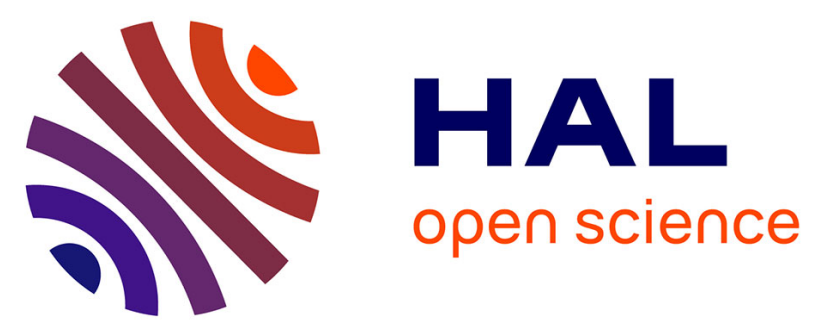

\title{
A Paleoseismic Record of Earthquakes for the Dead Sea Transform Fault between the First and Seventh Centuries C.E.: Nonperiodic Behavior of a Plate Boundary Fault
}

Neta Wechsler, Thomas. K. Rockwell, Yann Klinger, Petra Štěpančíková, Mor Kanari, Shmuel Marco, Amotz Agnon

\section{To cite this version:}

Neta Wechsler, Thomas. K. Rockwell, Yann Klinger, Petra Štěpančíková, Mor Kanari, et al.. A Paleoseismic Record of Earthquakes for the Dead Sea Transform Fault between the First and Seventh Centuries C.E.: Nonperiodic Behavior of a Plate Boundary Fault. Bulletin of the Seismological Society of America, 2013, 10.1785/0120130304 . insu-01304944

\section{HAL Id: insu-01304944 https://hal-insu.archives-ouvertes.fr/insu-01304944}

Submitted on 20 Apr 2016

HAL is a multi-disciplinary open access archive for the deposit and dissemination of scientific research documents, whether they are published or not. The documents may come from teaching and research institutions in France or abroad, or from public or private research centers.
L'archive ouverte pluridisciplinaire $\mathbf{H A L}$, est destinée au dépôt et à la diffusion de documents scientifiques de niveau recherche, publiés ou non, émanant des établissements d'enseignement et de recherche français ou étrangers, des laboratoires publics ou privés. 


\title{
A Paleoseismic Record of Earthquakes for the Dead Sea Transform Fault between the First and Seventh Centuries C.E.: Nonperiodic Behavior of a Plate Boundary Fault
}

\author{
by Neta Wechsler, Thomas K. Rockwell, Yann Klinger, Petra Štěpančíková, \\ Mor Kanari, Shmuel Marco, and Amotz Agnon
}

\begin{abstract}
We present new results from a paleoseismic trenching campaign at a site across the Jordan Gorge Fault (JGF), the primary strand of the Dead Sea Transform in northern Israel. In addition to the previously recognized earthquakes of 1202 and 1759 C.E., we observe evidence for eight surface-rupturing earthquakes prior to the second millennium C.E. The past millennium appears deficient in strain release with the occurrence of only two large ruptures, when compared with the preceding 1200 years. Assuming Gutenberg-Richter magnitude-frequency distribution, there is a discrepancy between measured rate of small-magnitude earthquakes $(\mathbf{M}<4)$ from instrumental records and large earthquake rates from paleoseismic records. The interevent time of surface-rupturing earthquakes varies by a factor of two to four during the past $2 \mathrm{ka}$ at our site, and the fault's behavior is not time predictable. The JGF may be capable of rupturing in conjunction with both of its southern and northern neighboring segments, and there is tentative evidence that earthquakes nucleating in the Jordan Valley (e.g., the 749 C.E. earthquake) could either rupture through the stepover between the faults or trigger a smaller event on the JGF. We offer a model of earthquake production for this segment in which the long-term slip rate remains constant while differing earthquake sizes can occur, depending on the segment from which they originated and the time since the last large event. The rate of earthquake occurrence in this model does not produce a time-predictable pattern over a period of $2 \mathrm{ka}$ as a result of the interplay between fault segments to the south and north of the JGF.
\end{abstract}

Online Material: High-resolution photomosaic logs of trench walls probability density function (PDF) and table of unit descriptions for channels 3 and 4.

\section{Introduction}

Quantifying short- and long-term fault behavior is essential to the understanding of fundamental processes that govern large earthquake production along plate boundary faults and to improve the ability to accurately forecast future large ruptures for seismic-hazard analysis (Working Group on California Earthquake Probabilities [WGCEP], 2007). Models used to forecast future seismicity make fundamental yet sometimes contradicting assumptions about the behavior of faults and fault systems, such as that they behave in a periodic fashion (Reid, 1910; Bakun and McEvilly, 1984), that they have characteristic ruptures (Schwartz and Coppersmith, 1984; Sieh, 1996; Zielke et al., 2010; Klinger et al., 2011), or that their behavior is variable in time and space (Weldon et al., 2004; Field and Page, 2011). These assumptions concerning fault behavior have been made based on insufficient observations, due in part to the relatively short time passed since the advent of instrumental seismology and in part to the incomplete (in time and/or space) record than can be gleaned from longer-term sources such as historical texts, paleoseismic records, or geomorphological studies. Nevertheless, in areas where long historical records exist and where earthquake geology and paleoseismology are combined with archeology, it may be possible to determine earthquake production, and potentially slip and slip distribution, through many earthquake cycles.

The Dead Sea Transform (DST) is an excellent candidate for the development of an extended earthquake record. In Israel and surrounding regions, there is a long historical record of earthquakes (3000-4000 year), yet the specifics about which fault section actually ruptured, or the amount of displacement in those events, is generally unknown. Most of the primary DST fault zone from Lebanon southward to the Gulf 
of Aqaba has not produced a surface-rupturing earthquake for the past $800-1000$ years, allowing some researchers to argue that the fault zone is overdue for one or more large earthquakes (Ferry et al., 2007, 2011), based on an assumption of quasiperiodic earthquake recurrence for individual fault segments. Conversely, some authors have suggested that earthquakes along the DST are clustered in time, over scales of $10 \mathrm{ka}$ (Marco et al., 1996) and 1-2 ka (Migowski et al., 2004), albeit these studies were based on event records that were not measured directly on specific faults, but rather inferred from disturbed lacustrine sediment records.

Some long records of large earthquakes on major faults give evidence of periods of quiescence and clustering and of earthquake production that has not been particularly periodic (Fumal et al., 2002; Rockwell et al., 2003; Ninis et al., 2013). This was attributed to the existence of multiple, parallel faults that may interact by stress loading when one large earthquake adjusts the timing on adjacent strands (King et al., 1994; Rockwell, 2010; Rockwell and Klinger, 2013; Rockwell et al., 2013). On the contrary, along the DST in Israel, almost all recognized strike-slip motion occurs in a narrow zone, bounded in places by secondary normal faults. There are no parallel major strike-slip faults (disregarding possible overlaps in structurally complex zones) that would allow for stress interaction until one goes northward into Lebanon and Syria (Fig. 1). In addition, the DST is composed of relatively straight segments with stepovers between them, allowing us to test the influence of segmentation and displacement on jumping steps of various widths (Wesnousky, 2008).

In this study, we expand the earthquake record along the DST in northern Israel by more than a thousand years, to the beginning of the first millennium C.E., using paleoseismic trenching techniques. By comparing our results with records obtained on the Jordan Valley fault to the south (Ferry et al., 2007) and on the various faults to the north (Gomez et al., 2003; Däeron et al., 2005, 2007) of our study area (Fig. 1), we can test the applicability of various earthquake recurrence models and whether the DST behaves in a predictable fashion.

\section{Geological Background}

The DST is a major plate boundary in the Middle East, accommodating the relative sinistral motion between the African and Arabian plates (Quennell, 1956), both moving northward with respect to Eurasia with differing velocities (Reilinger and McClusky, 2011). The DST transfers slip northward from the oblique opening of the Red Sea to the East Anatolian fault zone (Fig. 1a). The cumulative offset of the DST is $\sim 105 \mathrm{~km}$, representing the total motion between the Arabian plate and Sinai subplate since the middle Miocene (e.g., Freund et al., 1968; Garfunkel, 1981). The rate of ongoing sinistral motion measured across the fault from Global Positioning System (GPS) kinematics is estimated to be between 3 and $7 \mathrm{~mm} /$ year in northern Israel (Reilinger et al., 2006; Le Beon et al., 2008, and references therein).

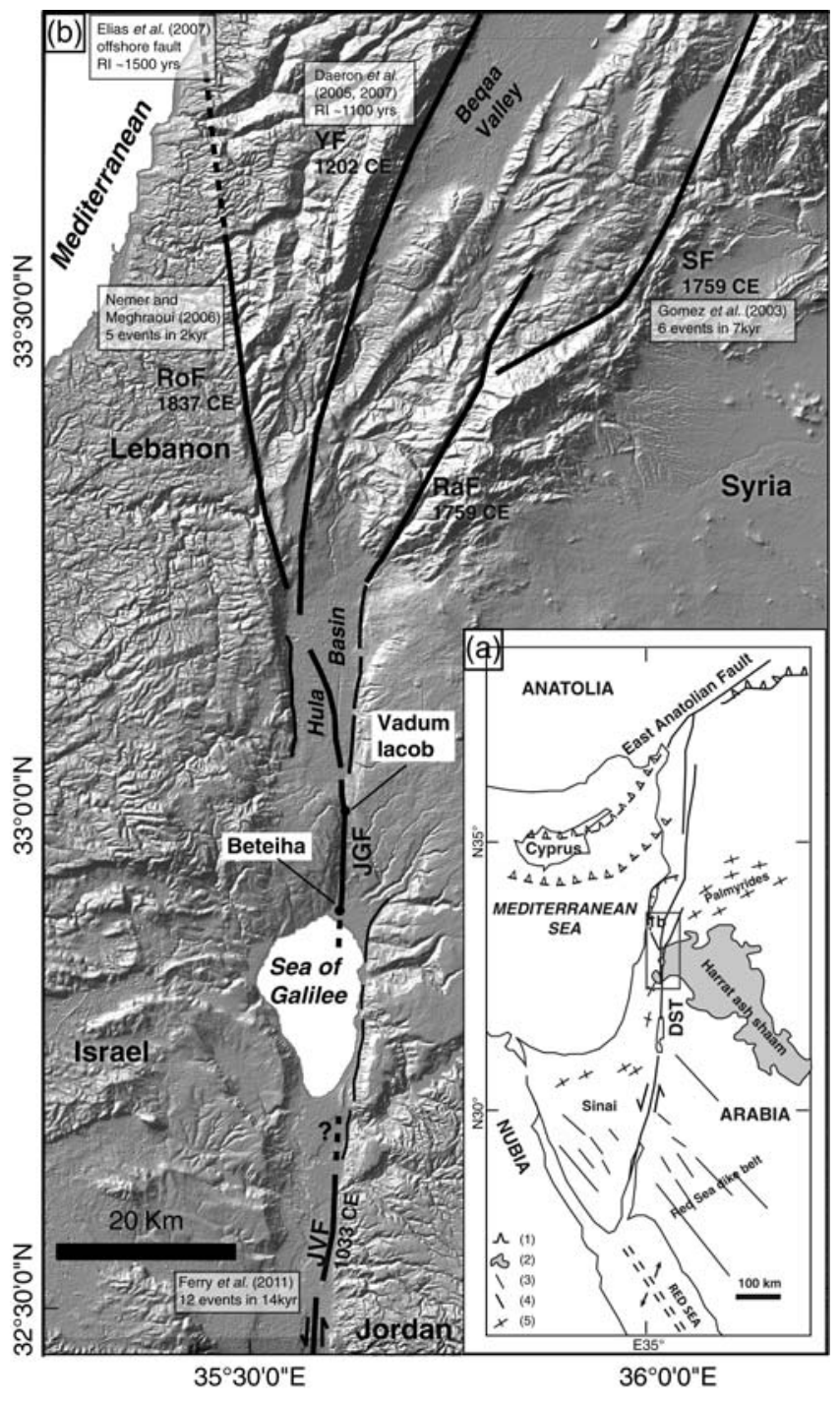

Figure 1. (a) Generalized tectonic framework of the Dead Sea Transform (DST) and other major structures in the area. Legend: (1) collision zones, (2) Cenozoic volcanics, (3) Early Miocene dykes, (4) plate boundary main faults, and (5) Syrian arc folds (after Garfunkel, 1989). (b) Location of major and minor faults of the DST in the vicinity of Hula basin and the Sea of Galilee. JGF, Jordan Gorge fault; JVF, Jordan Valley fault; RaF, Rachaya fault; RoF, Roum fault; SF, Serghaya fault; YF, Yammouneh fault. The latest earthquake known to have ruptured is mentioned below each fault name. Previous paleoseismic studies on fault branches are in outlined white boxes, together with recurrence information as provided by the authors (RI denoted recurrence interval). Topography from ASTER GDEM (ASTER GDEM is a product of Ministry of Economy, Trade, and Industry [METI] and National Aeronautics and Space Administration [NASA]).

In the northernmost part of Israel, in the Hula basin area, the DST deviates into a restraining bend and branches from a single, relatively straight fault into several subparallel strands (Fig. 1b). The main strike-slip fault runs from the Jordan Valley, entering the Sea of Galilee from the south where it continues north underwater next to its eastern shores; its precise location inside the lake basin has been difficult to determine (Ben-Gai, 2010). At the northern shore of the Sea of 
Galilee, the fault emerges in the Bet-Zayda (Beteiha) floodplain approximately $2-3 \mathrm{~km}$ to the west of its northward projection, implying the existence of a pull-apart basin within the lake (Marco et al., 2005; Meiler et al., 2011). From there, a single main segment continues north, producing a faultcontrolled river gorge (the Jordan Gorge fault [JGF] in Fig. 1b). Upon entering the Hula basin, the fault splits into eastern and western segments (Heimann, 1990; Rybakov et al., 2003; Heimann et al., 2009), which extend to the Rachaya-Serghaya and the Yammouneh faults, respectively (Fig. 1b). An additional branch, the Roum fault, extends from the northwest of the Hula basin, striking north-northwest for about $35 \mathrm{~km}$ (Fig. 1b). The Sea of Galilee basin is considered to be a barrier for large earthquakes, whereas the Hula basin is not, based on paleoseismic and gravity data (Marco et al., 2005; Schattner and Weinberger, 2009). Our work is focused on the Jordan Gorge segment between the Sea of Galilee and the Hula basin, where the fault location is known and only one main strand is thought to accommodate most of the ongoing sinistral movement, although a small amount may be accommodated by block rotation of the elevated saddle between the Sea of Galilee and the Hula basin (Heimann and Ron, 1993).

In previous works, the rupture history of the JGF was explored at two sites that are spaced about $15 \mathrm{~km}$ apart (Fig. 1b). At the Vadum Iacob site (also referred to as Ateret; Ellenblum et al., 1998), it was established that a Crusader castle had been sinistrally offset by $2.1 \mathrm{~m}$, out of which $1.6 \mathrm{~m}$ of displacement is attributed to the well-documented historical earthquake of 1202 C.E. (Ellenblum et al., 1998), to which Ambraseys and Melville (1988) assign a magnitude of 7.6. A more recent event offsets an Ottoman mosque constructed above the ruins of the castle by an additional $0.5 \mathrm{~m}$ (Ellenblum et al., 1998). The $0.5 \mathrm{~m}$ offset is attributed to the October 1759 earthquake, in which the damage was centered on the Jordan Gorge segment (Ambraseys and Barazangi, 1989). Recent excavations have revealed a Hellenistic wall (dated to the second century B.C.E.) that is offset by $\sim 6 \mathrm{~m}$, and an Iron Age wall on the west side of the fault that is offset by at least $8 \mathrm{~m}$, with its east side counterpart likely north of the excavated zone and therefore still unearthed (Ellenblum et al., 2013).

Marco et al. (2005) excavated paleoseismic trenches at a second location across the Jordan Gorge segment at the Beteiha site and exposed a number of buried channels that were offset by the fault. They resolved the timing and displacement of the last two events and, similar to Vadum Iacob, estimated the displacement in the 1202 earthquake as $\sim 2.2 \mathrm{~m}$, with an additional $0.5 \mathrm{~m}$ of sinistral displacement attributed to the 1759 earthquake, a total of $2.7 \mathrm{~m}$. A fourth channel that dates between 3 and $5 \mathrm{ka}$ is displaced up to $15 \mathrm{~m}$, yielding a minimum $3 \mathrm{~mm} /$ year slip rate for the late Holocene (Marco et al., 2005).

Other paleoseismic works on adjacent segments of the DST include Ferry et al. (2011) who recorded 12 faulting events within the past $14 \mathrm{ka}$ on the Jordan Valley segment to the south (Fig. 1b) and calculated an approximate slip rate of $3.3 \mathrm{~mm} / \mathrm{yr}$ based on an inferred displacement of $3.3 \mathrm{~m}$ per event. Yet, they point out that their record contains sedimentary hiatuses and is therefore incomplete, except for the last five earthquakes. Moreover, the recurrence interval between earthquakes for those last five events is highly variable, between 284 and 1508 years. North of the Hula basin, Däeron et al. $(2005,2007)$ trenched across the Yammouneh fault in the Bekka Valley (Fig. 1b) and found evidence for 10-13 surface-rupturing earthquakes within the last $12 \mathrm{ka}$, yielding an average recurrence interval of $\sim 1100$ years, though the large uncertainty in event ages, especially the older ones ( $\pm 2 \sigma$ larger than 600 years), does not support the assumption of periodicity. Gomez et al. (2003) studied the Serghaya fault (Fig. 1b), which last ruptured in the November 1759 earthquake, and determined that the penultimate event was approximately 2 millennia earlier. They have found evidence of six events over the last $7 \mathrm{ka}$, but the poorly constrained timing of past events did not permit a reliable estimate of the recurrence interval. Nemer and Meghraoui (2006) trenched across the Roum fault (Fig. 1b) and found evidence for five events during the past $2 \mathrm{ka}$, but the dates were not sufficiently well constrained to permit a good estimate of the recurrence interval. Elias et al. (2007) studied the Mt. Lebanon thrust fault, surfacing primarily offshore, and determined that it was the source for the 551 C.E. earthquake and tsunami. They documented evidence that the fault generates large earthquakes every 1500-1750 years, based on uplifted Holocene marine terraces, and may possibly rupture together with the Roum fault. None of the above studies demonstrate clear evidence for periodic earthquake production along the DST, and some aforementioned records may even be interpreted as exhibiting strong temporal clustering. To test the behavior of the JGF section of the northern DST, we conducted new extensive paleoseismic investigations in the Bet-Zayda Valley, including both $2 \mathrm{D}$ and $3 \mathrm{D}$ trenches to resolve both timing and displacement, with timing being the focus of this paper. The new work presented here greatly expands our knowledge of the earthquake history of this part of the fault for the past two millennia and allows a better assessment of both the behavior of this fault, as well as the likelihood of future earthquake activity in the region.

\section{Paleoseismic Investigations}

\section{Site Description}

The Beteiha site is located in a cultivated field just north of the Sea of Galilee near a mound associated with the historical village of Bet-Zayda (Figs. 1 and 2), close to where the Jordan River debouches sediments into the lake. The site is on a relatively flat alluvial plain crossed by the DST fault scarp and is unique in that small west-flowing streams originating from the northeast cross the plain, and consequently the fault, to drain into the Jordan River (Figs. 1b and 2a). Starting in the early 1970s, the Bet-Zayda plain has been artificially drained, but in the past it was sometimes flooded by the Jordan River in the spring (personal communication 
(a)

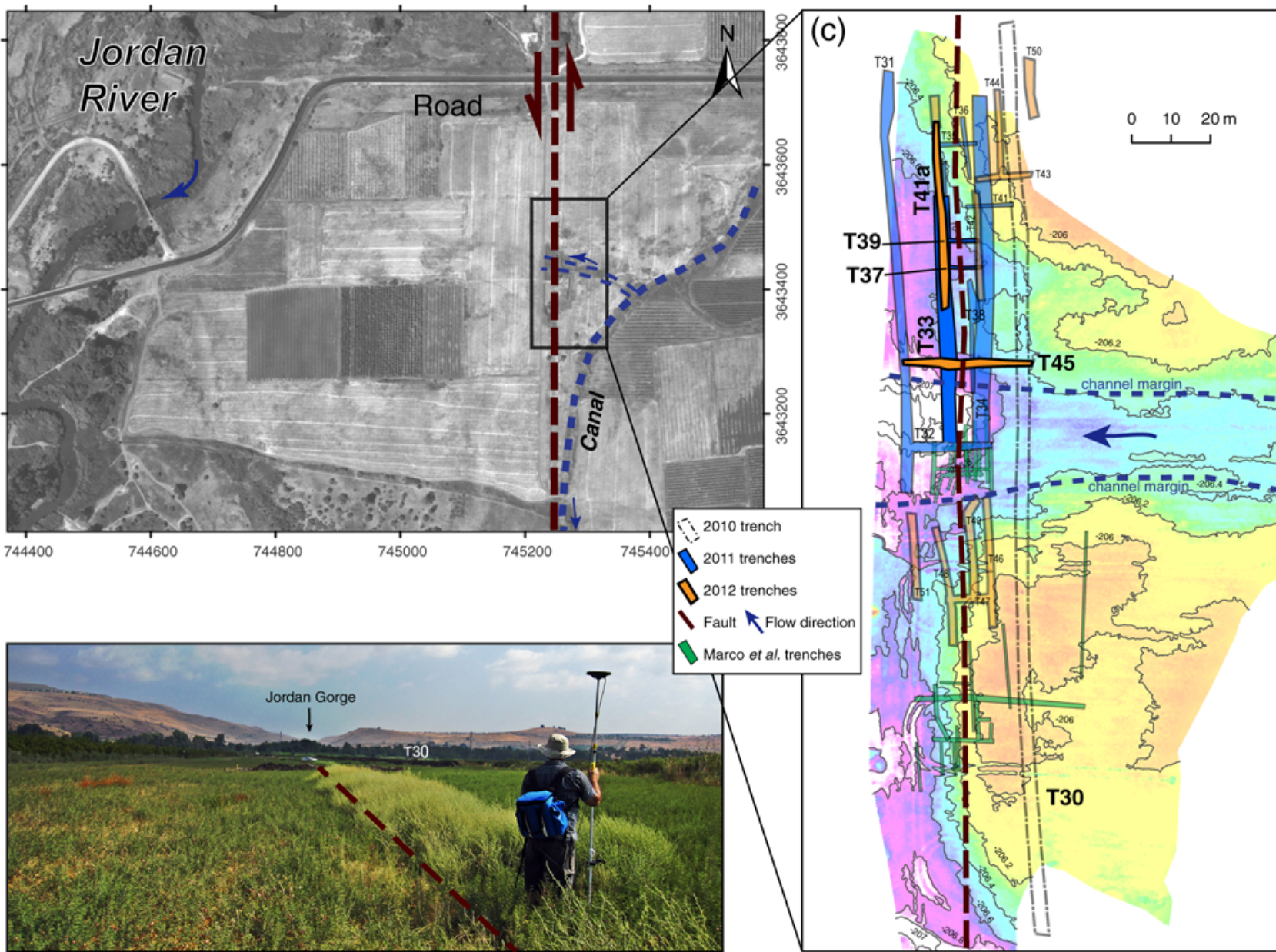

Figure 2. General settings of the Beteiha site. (a) An air photo of the field where the trenches were excavated, with the Jordan River, the main fault, and the local drainage demarcated. The channel flowing west through the trench site (double thin-dashed line) is abandoned and the field is now drained by the marked artificial canal (short thick-dashed line). (b) A photo of the trench site at the beginning of the firsttrenching campaign, looking north toward the Jordan Gorge. A white car stands next to T30. A vegetation lineament associated with the fault is visible at the front. (c) The trench site with outlines for all trenches dug during our campaign, as well as the location of Marco et al. (2005) trenches. The trenches discussed in this paper are highlighted and labeled. The modern channel margins are marked by a dashed line. The topography model was obtained using a terrestrial laser scanner prior to second-year trenching, courtesy of O. Katz from the Geological Survey of Israel. The contour lines represent variations in elevation. The color version of this figure is available only in the electronic edition.

from local farmers, Fig. 2a). The site was initially trenched by Marco et al. (2005) as previously described in this paper. The fault geomorphic expression in the field is weak. There is a gentle topographic scarp, with the east side less than $1 \mathrm{~m}$ higher than the west side (Fig. 2b and c).

The site elevation is $205-207$ meters below sea level (m.b.s.l.), whereas the present shore of the Sea of Galilee is about 212 m.b.s.l. Lake level reconstructions (Hazan et al., 2005 ) indicate the site was probably inundated by the lake at some point in the last 2000 years, in addition to being underwater during a highstand 5000 years ago that reached 200 m.b.s.l.

During the course of three field seasons, we excavated 21 paleoseismic trenches to depths of 3-5 m, totaling approximately $900 \mathrm{~m}$ in length (Fig. 2). We initially opened a $305 \mathrm{~m}$ long exploratory trench (T30) to locate and date buried channels and were able to identify a total of 15 channels. Four of the channels were studied by Marco et al. (2005), whereas the other 11 were previously unknown. We chose the seven most promising channels and excavated 20 additional trenches across these channels on both sides of the fault to resolve displacement and explore the rupture history (Fig. 2c). In this paper, we present the results on the timing of past earthquakes, as recorded in the channel stratigraphy in the faultcrossing trenches T37, T39, and T44 and the fault-parallel trenches T33 and T41a (Fig. 2c). We focus on the channels that were active between 2 and $1 \mathrm{ka}$ B.P. to extend the paleoseismic earthquake record published by Marco et al. (2005). The rest of the channels did not provide adequate stratigraphy across the fault and are not discussed in this paper.

\section{Stratigraphy}

The shallow subsurface stratigraphy is composed of several buried gravel- and sand-filled channels encased into 
Table 1

The Channels Found at the Beteiha Site, with Ages and General Descriptions

\begin{tabular}{|c|c|c|c|}
\hline Channel & Age & General Description & Comments \\
\hline $\mathrm{CH} 1$ & Seventh-fourteenth century C.E. & $\begin{array}{l}\text { A gravelly sandy channel complex, } \\
\text { many freshwater mollusc shells }\end{array}$ & $\begin{array}{l}\text { Previously studied channels by Marco et al. (2005) captures } \\
\text { the } 1202 \text { C.E. earthquake. }\end{array}$ \\
\hline $\mathrm{CH} 2$ & Seventh-eighth century C.E. & A sandy channel & Cuts the northern margin of $\mathrm{CH} 3$, east of the fault. \\
\hline $\mathrm{CH} 3$ & Fifth-seventh century C.E. & $\begin{array}{l}\text { A gravelly sandy channel complex } \\
\text { with cross-cutting units }\end{array}$ & South margin cut by $\mathrm{CH} 1$, north margin by $\mathrm{CH} 2$. \\
\hline $\mathrm{CH} 4$ & First-fourth century C.E. & A sandy gravelly channel complex & Better preserved west of the fault due to vertical offset. \\
\hline $\mathrm{CH} 5$ & First-third century C.E. & $\begin{array}{l}\text { A V-shaped gravelly channel, possibly } \\
\text { man-made }\end{array}$ & Only trenched east of the fault; not discussed in this paper. \\
\hline $\mathrm{CH} 6$ & Tenth-fourth century B.C.E. & $\begin{array}{l}\text { Distinct red unit, more of a flood } \\
\text { surface than a channel }\end{array}$ & $\begin{array}{l}\text { Divided into two sub units, which are at different depths; } \\
\text { used to constrain } \mathrm{CH} 4 \text { age as it appears directly below it. }\end{array}$ \\
\hline
\end{tabular}

massive lacustrine clays deposited during lake highstands. The ages and general descriptions of the buried channels are summarized in Tables 1 and (E) S1 (available in the electronic supplement to this article). We numbered the channels according to their relative age, starting with the channel 1 complex, which is composed of three distinct subchannels. These were previously excavated and described by Marco et al. (2005). Channels 2, 3, and 4, each also composed of multiple subchannels, record fluvial flow across the fault during most of the first millennium (Table 1). The channels that Marco et al. (2005) excavated were dated from the ninth century to at least as young as the fourteenth century C.E., when the channel complex was buried by lake deposits. The modern channel may have been active after the lake level dropped and up until about the 1970s, when artificial drains were excavated to improve the drainage for agriculture (Fig. 2a and c). Thus, collectively, these channels and lake deposits contain the complete displacement and earthquake history for the past 2000 years.

Channels 3 and 4 each spanned several centuries of time, and trenches excavated to expose these channels across the fault exhibited clear evidence of multiple earthquakes having occurred while they were active. In contrast, all of the dates from channel 2 fall within a short, 100-year time period centered around 720 C.E, indicating that this channel represents a fairly short period of flow. We did not trench channel 2 across the fault; however, from cross-cutting relations in T34 and T38, we inferred that channel 2 is younger than channel 3 (E) Fig. S1i available in the electronic supplement). Consequently, we focus now on the event evidence recorded in the stratigraphy of channels 3 and 4 , as described next.

\section{Channel 3}

Channel 3 is a west-flowing sandy gravelly channel complex that was crossed in several fault parallel trenches (T30, T33, T34, and T38) and in one fault-crossing trench (T45). The channel units were numbered between 300 and 399 (older units $=$ higher numbers) for reference. T45, the fault-crossing trench, also represents a longitudinal profile of channel 3 and was used to study earthquake history. The logs of T45 are presented in Figures 3 and (E) S1a-b, and the unit nomenclature is described in Table $\mathrm{S} 1$ available in the electronic supplement. Channel 3 was divided into lower and upper units based on the channel morphology, with the upper units (units 306-329) cutting into and eroding the lower units (units 330-399) east of the fault (T45 log, Figs. 3 and (E) S1a-b available in the electronic supplement). These upper units strata were not observed in fault contact on the west side of the fault. The youngest units (301-305) are capping the faults on the west side and appear unrelated to the upper channel 3 units. The strata in channel 3 vary in composition from large, rounded pebbles and cobbles at the base of individual subchannels in the lower part of the section, to foresetbedded gravelly sand and silty clay in the upper part. Furthermore, the upper part (units 310-329) of channel 3 exhibits an anomalous trend on the east side of the fault zone, with indications of an along-fault flow direction (northsouth). The upper part also has many gastropod shells within it, indicating a rise in lake level and probable influence from motion on the eastern fault strand, as discussed later. The foreset bedding (units 320-328) is also consistent with deposition in standing water, which supports the inference of an increase in lake level.

We collected nearly 100 samples of detrital charcoal from the strata of channel 3, of which 36 were dated by ${ }^{14} \mathrm{C}$ mass spectroscopy methods at the Center for Accelerator Mass Spectrometry (CAMS) facility at University of California, Irvine. Twenty-eight of these dates are from trench T45 or from strata exposed in fault-parallel trenches near T45 that could be confidently traced into the strata of T45 (indicated as proxy dates on the trench logs) and are used in this paper. Many of the samples yielded dates that are much older than other samples from the same stratum, including one as old as 12,000 years. Consequently, not all were used in the chronologic model to constrain the ages of faulting events exposed in T45. Taking the youngest dates from each unit as closest to the actual age of their respective strata, and discarding dates that are out of stratigraphic sequence, we are left with 10 dates that we used in our chronologic model (Fig. 4). From these, the ages of the lower strata from channel 3 range from the mid-fifth century C.E. to the mid-seventh century C.E., 


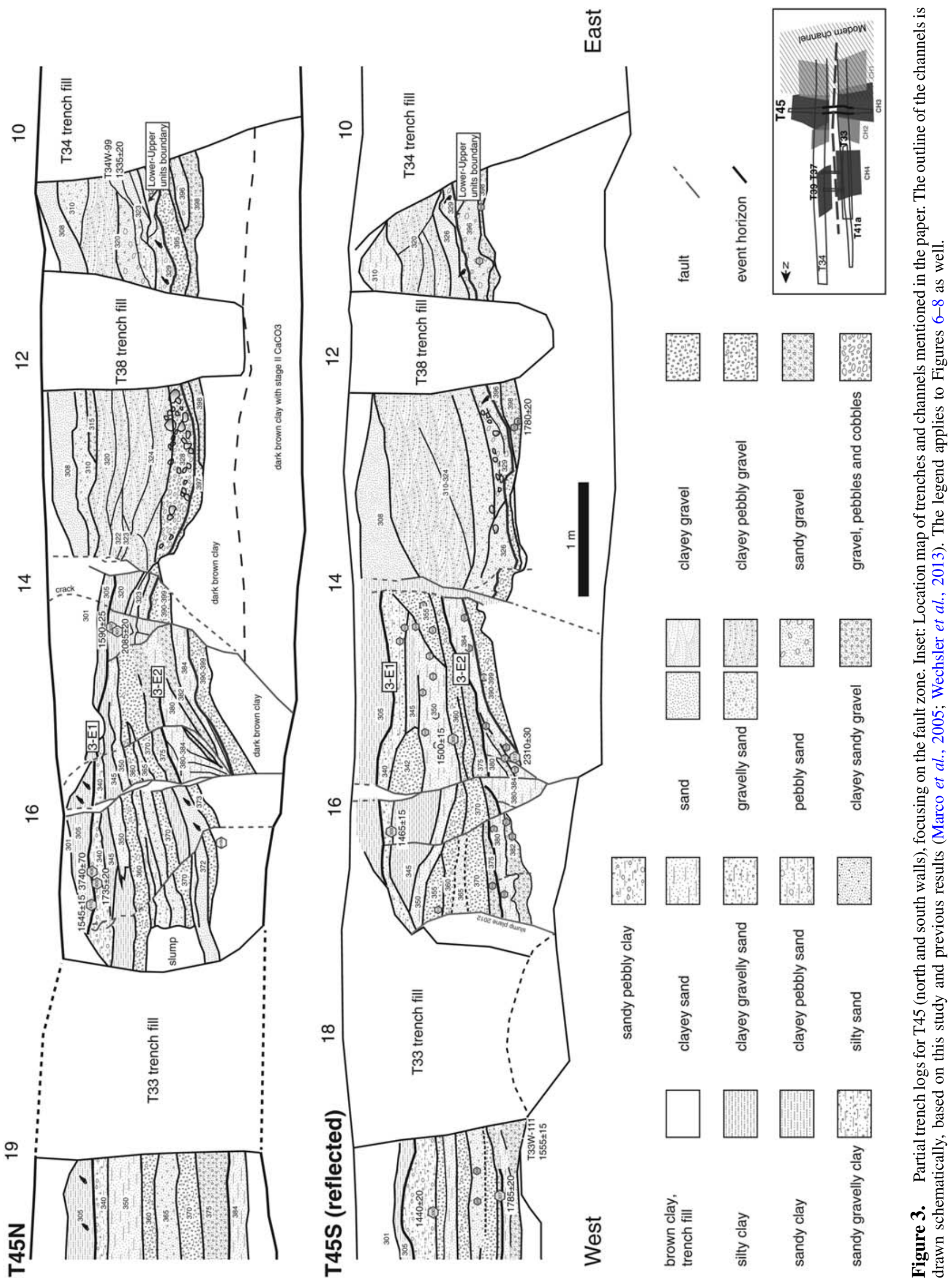




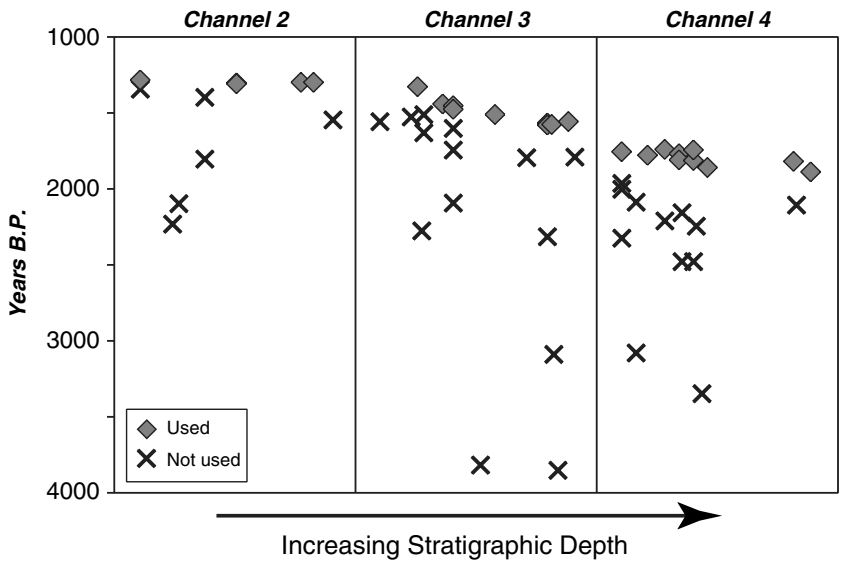

Figure 4. Uncalibrated sample ages versus increasing stratigraphic depth, expressed by unit number. We assume that older samples have inheritance issues (old wood problem) and therefore use only the youngest samples from each channel in our OxCal model.

whereas a single date from the upper portion of channel 3 yielded a mid-seventh to mid-eighth century date. As an additional age constraint, we used 5 of the 11 radiocarbon dates from channel 2 that span the entire section of the channel as an upper-bound constraint on the ages of strata in channel 3, based on cross-cutting relations from fault parallel trenches (E) Fig. S1i available in the electronic supplement). All five dates yielded ages in the late-seventh to mid-eighth century C.E., consistent with the date from the upper part of channel 3 and suggesting there is not much time between the abandonment of channel 3 and formation of channel 2, although the stratigraphic evidence indicates a rise in lake level. A lake level rise may have forced the avulsion from channel 3 to channel 2, an event that may have occurred in only a few decades, or less, as suggested by the ${ }^{14} \mathrm{C}$ dates. We also used Marco et al. (2005) samples to constrain the youngest event in channel 3. Dates are modeled using OxCal (BronkRamsey, 2009) and IntCal 09 calibration-curve (Reimer et al., 2009), as summarized in Figure 5 and Table 2.

Trench T45 exposes evidence for two surface ruptures captured in the stratigraphy of channel 3 (Fig. 3), which we number $\mathrm{CH} 3-\mathrm{E} 1$ and $\mathrm{CH} 3-\mathrm{E} 2$. Event names represent the channel in which they are identified (the first number) and their stratigraphic order from younger (E1) to older (E2). There is also evidence for displacements younger than E1 that involved the overlying strata, and these are most likely the previously documented 1202 and 1759 C.E. earthquakes and any other events that postdate channel 3 . The fault zone itself, as exposed in T45, is divided into two main strands, 1-2 $\mathrm{m}$ apart, plus several subsidiary faults. The eastern strand truncates the manganese-stained, cross-bedded upper channel 3 sandy gravel strata (units 320-329). Within and west of the fault zone, units attributed to the lower section of channel 3 are preserved across all fault strands and contain the evidence for the surface ruptures. Hence, the two surface ruptures we identify fall in the time frame of the lower channel 3

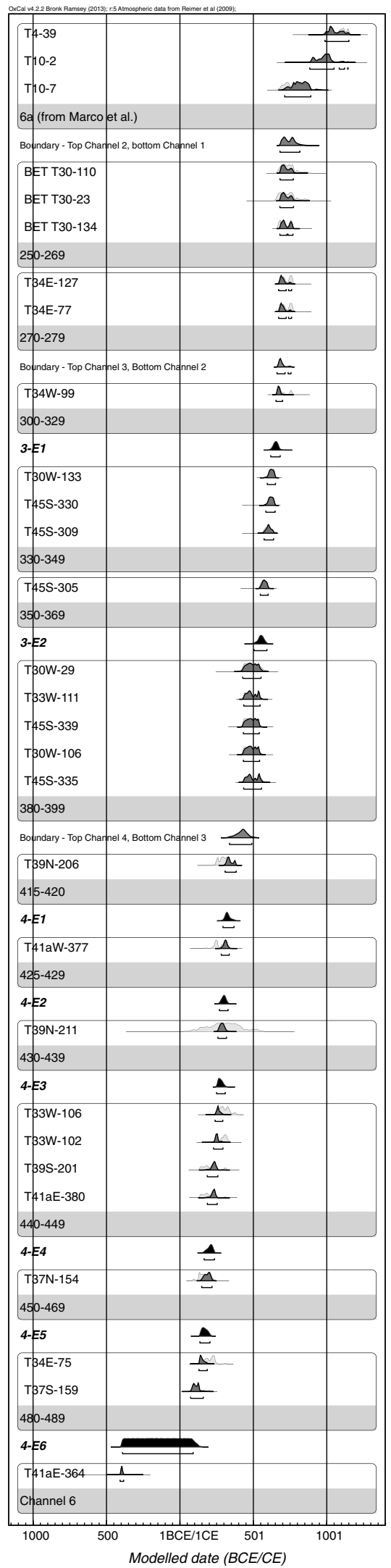

Figure 5. An OxCal model of the overall stratigraphy of the channel complex using OxCal 4.1 (Bronk-Ramsey, 2009). We use the Marco et al. (2005) ages as an upper bound for our model, and a sample obtained from below channel 4 as a lower bound. 
Table 2

Results of Radiocarbon Dating and OxCal Modeling of Samples

\begin{tabular}{|c|c|c|c|c|c|c|}
\hline Channel & $\begin{array}{l}\text { Sample } \\
\text { Number }\end{array}$ & Location & $\begin{array}{l}\text { Stratigraphic } \\
\text { Unit }\end{array}$ & $\delta^{13} \mathrm{C}^{*}$ & Age B.P. & $\begin{array}{l}\text { Modeled Calibrated } \\
\text { Age }( \pm 2 \sigma)^{\dagger}\end{array}$ \\
\hline \multirow[t]{6}{*}{$\mathrm{CH} 1$} & T10-5 & T10 & $6 \mathbf{b}$ & 26.2 & $560 \pm 35$ & 1298-1424 C.E. \\
\hline & T10-1 & T10 & $\mathbf{6 b}$ & 25 & $680 \pm 85$ & 1206-1412 C.E. \\
\hline & T2-30 & $\mathbf{T} 2$ & 6b & - & $810 \pm 45$ & 1165-1279 C.E. \\
\hline & T4-39 & $\mathbf{T 4}$ & $6 a$ & 25.4 & $980 \pm 40$ & 988-1152 C.E. \\
\hline & T10-2 & T10 & $6 \mathbf{a}$ & 25.4 & $1045 \pm 50$ & 885-1146 C.E. \\
\hline & T10-7 & T10 & $6 \mathbf{a}$ & 24.1 & $1230 \pm 40$ & 714-892 C.E. \\
\hline \multirow[t]{5}{*}{$\mathrm{CH} 2$} & 110 & T30W & 220 & - & $1270 \pm 35$ & 682-773 C.E. \\
\hline & 23 & T30W & 250 & - & $1290 \pm 50$ & 681-774 C.E. \\
\hline & 134 & T30W & 250 & -25.9 & $1295 \pm 20$ & 681-771 C.E. \\
\hline & 127 & $\mathrm{~T} 33 \mathrm{~W}$ & 270 & -26.5 & $1285 \pm 15$ & 673-761 C.E. \\
\hline & 77 & T34E & 274 & -28.0 & $1285 \pm 15$ & 673-761 C.E. \\
\hline \multirow[t]{24}{*}{$\mathrm{CH} 3$} & 410 & $T 45 N$ & 305 & - & $1545 \pm 15$ & - \\
\hline & 90 & $T 34 E$ & 320 & -24.3 & $1515 \pm 15$ & - \\
\hline & 99 & T34W & 323 & - & $1315 \pm 20$ & 655-700 C.E. \\
\hline & 313 & $T 45 S$ & 325 & - & $2270 \pm 20$ & - \\
\hline & 451 & $T 45 N$ & 326 & -23.8 & $1500 \pm 15$ & - \\
\hline & 336 & $T 45 S$ & 326 & -25.0 & $1620 \pm 20$ & - \\
\hline & 133 & T30W & 335 & -26.0 & $1430 \pm 20$ & 595-652 C.E. \\
\hline & 330 & $\mathrm{~T} 45 \mathrm{~S}$ & 340 & -23.9 & $1440 \pm 20$ & 586-649 C.E. \\
\hline & 309 & $\mathrm{~T} 45 \mathrm{~S}$ & 340 & -24.0 & $1465 \pm 15$ & 574-639 C.E. \\
\hline & 402 & $T 45 N$ & Fissure fill ${ }^{\ddagger}$ & -25.7 & $1590 \pm 25$ & - \\
\hline & 409 & $T 45 N$ & Fissure fill ${ }^{\ddagger}$ & - & $1735 \pm 20$ & - \\
\hline & 401 & $\mathrm{~T} 45 \mathrm{~N}$ & 340 & -26.2 & $2085 \pm 20$ & \\
\hline & 307 & $\mathrm{~T} 45 \mathrm{~S}$ & 353 & - & $3825 \pm 25$ & \\
\hline & 305 & $\mathrm{~T} 45 \mathrm{~S}$ & 360 & -23.9 & $1500 \pm 15$ & 548-602 C.E. \\
\hline & 327 & $T 45 S$ & 345 & -19.9 & $1785 \pm 20$ & - \\
\hline & 111 & T33W & 385 & -27.1 & $1555 \pm 15$ & 435-547 C.E. \\
\hline & 29 & T30W & 385 & - & $1560 \pm 35$ & 428-553 C.E. \\
\hline & 339 & $\mathrm{~T} 45 \mathrm{~S}$ & 385 & -26.2 & $1570 \pm 20$ & 433-541 C.E. \\
\hline & 317 & $T 45 S$ & 385 & - & $2310 \pm 30$ & - \\
\hline & 106 & T30W & 387 & -22.5 & $1565 \pm 20$ & 433-543 C.E. \\
\hline & 345 & $T 45 S$ & 388 & - & $3090 \pm 60$ & - \\
\hline & 301 & $T 45 S$ & 390 & - & $3860 \pm 35$ & - \\
\hline & 335 & $\mathrm{~T} 45 \mathrm{~S}$ & 395 & -21.4 & $1545 \pm 20$ & 435-556 C.E. \\
\hline & 331 & $T 45 S$ & 398 & -24.3 & $1780 \pm 20$ & - \\
\hline \multirow[t]{21}{*}{$\mathrm{CH} 4$} & 206 & T39N & 420 & -27.1 & $1745 \pm 15$ & 308-384 C.E. \\
\hline & 203 & T39S & 420 & - & $1955 \pm 20$ & - \\
\hline & 396 & T41aE & 420 & - & $1995 \pm 15$ & - \\
\hline & 202 & T39S & 420 & - & $2320 \pm 160$ & - \\
\hline & 156 & $T 37 N$ & 425 & - & $2080 \pm 240$ & - \\
\hline & 209 & $T 39 N$ & 425 & - & $3080 \pm 120$ & - \\
\hline & 377 & $\mathrm{~T} 41 \mathrm{aW}$ & 429 & -28.1 & $1770 \pm 20$ & 282-337 C.E. \\
\hline & 211 & $\mathrm{~T} 39 \mathrm{~N}$ & 435 & - & $1730 \pm 90$ & 259-318 C.E. \\
\hline & 393 & T41aE & 435 & -26.3 & $2205 \pm 20$ & - \\
\hline & 106 & $\mathrm{~T} 33 \mathrm{~W}$ & $440-449$ & & $1735 \pm 15$ & 240-293 C.E. \\
\hline & 102 & $\mathrm{~T} 33 \mathrm{~W}$ & $440-449$ & -22.8 & $1760 \pm 15$ & 230-294 C.E. \\
\hline & 201 & T39S & $440-449$ & -27.5 & $1800 \pm 15$ & 187-259 C.E. \\
\hline & 105 & $T 33 W$ & $440-449$ & - & $2150 \pm 45$ & - \\
\hline & 380 & $\mathrm{~T} 41 \mathrm{aE}$ & $440-449$ & -21.3 & $1805 \pm 15$ & 187-255 C.E. \\
\hline & 394 & $T 41 a E$ & $440-449$ & -25.8 & $2475 \pm 20$ & - \\
\hline & $A 1$ & T4laW & $440-449$ & -27.2 & $2240 \pm 20$ & - \\
\hline & 381 & $T 41 a E$ & $440-449$ & - & $3350 \pm 120$ & - \\
\hline & 154 & $\mathrm{~T} 37 \mathrm{~N}$ & $450-460$ & -25.1 & $1850 \pm 15$ & 149-220 C.E. \\
\hline & 75 & $\mathrm{~T} 34 \mathrm{E}$ & $480-489$ & -21.4 & $1810 \pm 15$ & 137-206 C.E. \\
\hline & 165 & $T 37 S$ & $480-489$ & - & $2100 \pm 60$ & - \\
\hline & 159 & T37S & $480-489$ & -25.0 & $1880 \pm 15$ & 73-160 C.E. \\
\hline
\end{tabular}


Table 2 (Continued)

\begin{tabular}{ccccccc}
\hline Channel & $\begin{array}{c}\text { Sample } \\
\text { Number }\end{array}$ & Location & $\begin{array}{c}\text { Stratigraphic } \\
\text { Unit }\end{array}$ & $\delta^{13} \mathrm{C}^{*}$ & Age B.P. & $\begin{array}{c}\text { Modeled Calibrated } \\
\text { Age }( \pm 2 \sigma)^{\dagger}\end{array}$ \\
\hline Below 4 & 390 & T41aE & 499 & - & $3765 \pm 20$ & - \\
CH6 $^{\S}$ & 364 & T41aE & 510 & -24.9 & $2335 \pm 20$ & 392 B.C.E-91 C.E. \\
\hline
\end{tabular}

Mass spectroscopy measurements were made at the Keck carbon cycle mass spectroscopy facility at University of California, Irvine. Ages were calibrated using OxCal 4.2 (Bronk-Ramsey, 2009) and calibration curve INTCAL09 (Reimer et al., 2009). Samples from channel CH1 are from Marco et al. (2005) and are used as an upper bound. Samples in italics were considered outliers, and their ages were not modeled.

$* \delta^{13} \mathrm{C}$ is a measure of the ratio of the stable isotopes ${ }^{13} \mathrm{C}$ and ${ }^{12} \mathrm{C}$. When $\delta^{13} \mathrm{C}$ were not measurable, a value of -25.0 was used.

Dates in parentheses are for the alternative model.

†The sample is from a fissure that is capped by unit 315 .

${ }^{\S}$ The sample was taken from the top of channel $\mathrm{CH} 6$, where it appears below channel $\mathrm{CH} 4$ (巨) Fig. S1c available in the electronic supplement).

section, or between about the mid-fifth to mid-seventh centuries C.E. There are no equivalent upper channel 3 units exposed in T45 west of the eastern fault branch, except the capping units 301-305, which only appear west of the eastern fault branch, and therefore their stratigraphic relation with the younger units west of the fault is unclear. This could be a result of horizontal offset, of local changes in the channel flow near the fault zone, or both.

Event CH3-E1 is expressed on both trench walls as an upward truncation of fault strands that are capped by unit 305. In T45N, within the fault zone along a secondary fault strand, there is a large fissure that contains rotated blocks of coherent stratigraphy floating inside more massive fissurefill material (between 14 and $15 \mathrm{~m}$ ). Another fault strand that bounds the fault zone on the west also appears to rupture to the same stratigraphic position (at $17 \mathrm{~m}$ ), and both faults and the fissure fill are capped by unit 305 , whereas all other fault strands rupture to higher levels and presumably moved in later earthquakes. On the south wall of the trench, a single fault strand was found that ruptured up through the channel stratigraphy and was capped by unit 305 (at $16.5 \mathrm{~m}$ ). Taken together, we consider this strong evidence for a surfacerupturing event that occurred high in the section of the lower channel 3 alluvial fill. We speculate that this event, which produced uplift of the central block within the fault zone, may have caused local damming of channel 3, thereby disrupting the stratigraphy of upper channel 3 deposits.

Event CH3-E2 is also well expressed on both trench walls, with lower channel 3 alluvium of units 380-384 folded or tilted by as much as $30^{\circ}$ to the west and in fault contact, followed by truncation of these deformed strata and deposition of undeformed lower channel 3 alluvium. Both the deformed strata and secondary fault strands are capped by unit 375 , so we infer this contact to be the event horizon.

The ages of the surface-rupturing events interpreted in the sediments of channel 3 are presented as probability density functions in OxCal (Bronk-Ramsey, 2009) in the chronologic model in Figure 5. Based on this OxCal model, event CH3-E1 falls in the range of 619-684 C.E., with a peak prob- ability at about 653 C.E., whereas CH3-E2 is dated to between 505 and 593 C.E., with a peak probability at about 551 C.E. Because the probability distributions are nearly symmetric, we present them as $653 \pm 36$ C.E. and $551 \pm 42$ C.E., with uncertainties reported at $2 \sigma$.

\section{Channel 4}

The sandy channel complex of channel 4 was exposed in trenches T33, T37, and T39 (Figs. 6-8), with the latter two trenches crossing the fault. Captured within the strata of channel 4, we found evidence for up to six paleoearthquakes, which are numbered CH4-E1 through CH4-E6. The stratigraphic units in channel 4 are numbered 400-499, from youngest to oldest, and represent nearly continuous deposition of sand, gravel, and mud across the fault for several hundred years. Channel 4 crossed the fault in an area where a long, linear, and narrow pressure ridge is interpreted to have caused a very localized uplift within the fault zone itself. This is obvious in the expression of faulting, as exposed in trenches T37 and T39, where the strata of channel 4 are warped up into the fault. It is partly due to this localized style or expression of the fault that we were able to confidently distinguish individual faulting events.

Trench T33 was excavated west of the fault to identify channel locations, but we use the stratigraphy exposed in the vicinity of trench T37 and T39 to wrap all stratigraphic units in all three exposures, so correlation of strata are certain. From this exercise, two other important elements are apparent. First, the stratigraphy in trench T37 is mostly older than the strata exposed in T39, because T33 shows that strata offlap to the north west of the fault zone. Thus, as seen by the depositional relations between the units in T33 (Figs. 7 and (E) S1f available in the electronic supplement), strata are progressively older to the south on the west side of the fault, which is consistent with a model in which the faults motion during the period of channel flow created a progression of overlapping subchannels west of the fault, from the oldest in the south to the youngest in the north, consistent with the faults left-lateral motion. Second, there is a locally 


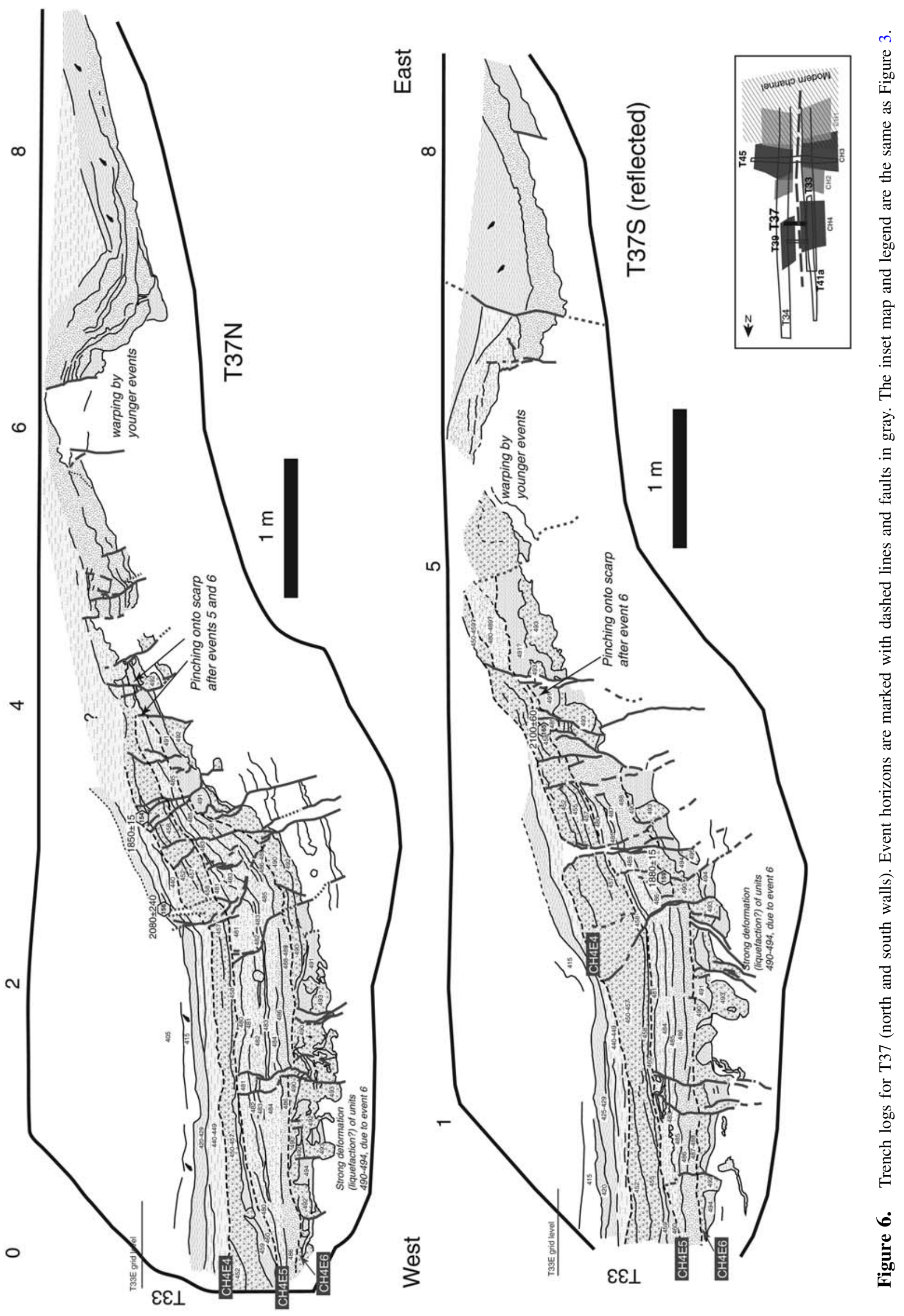




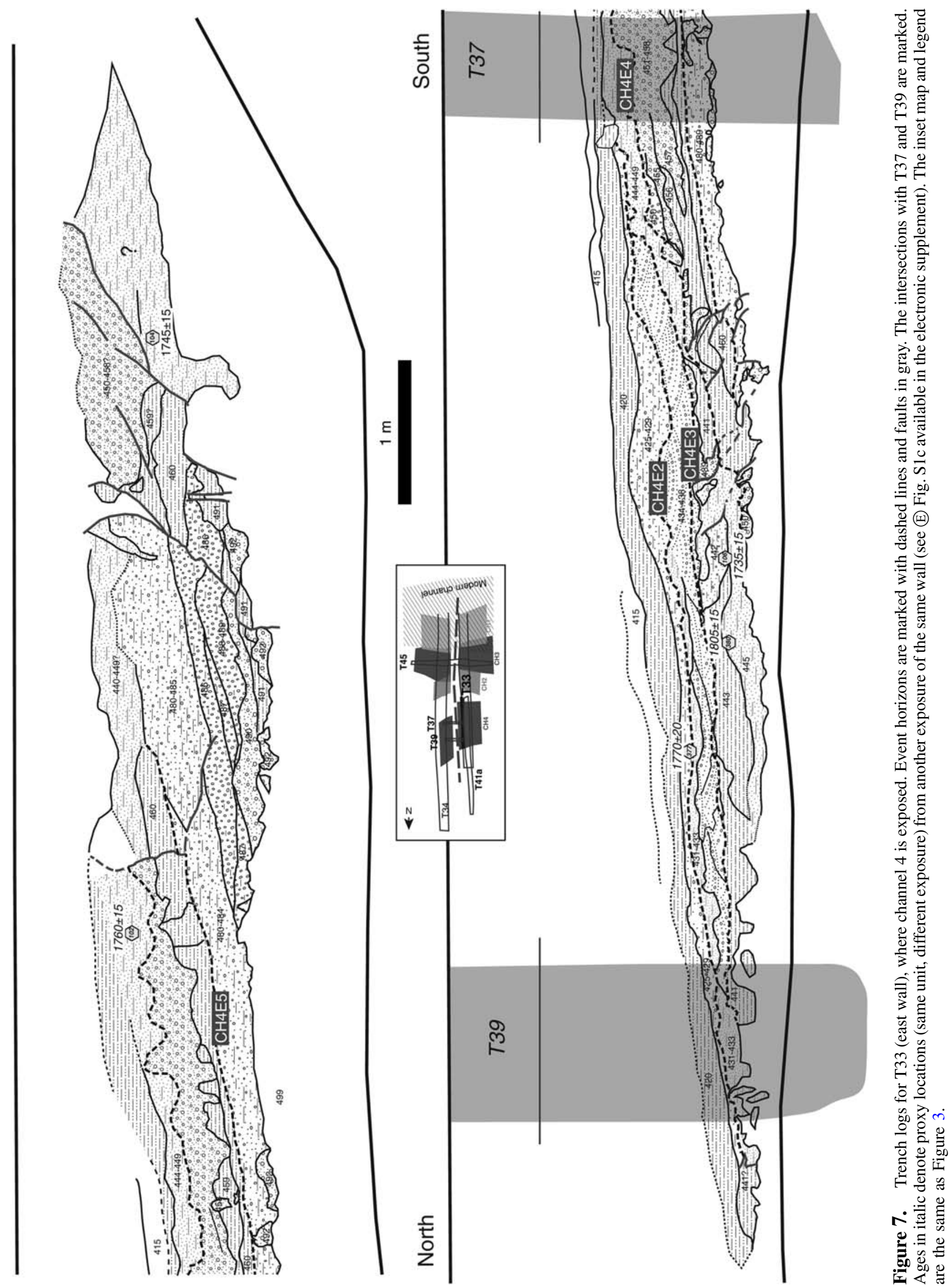




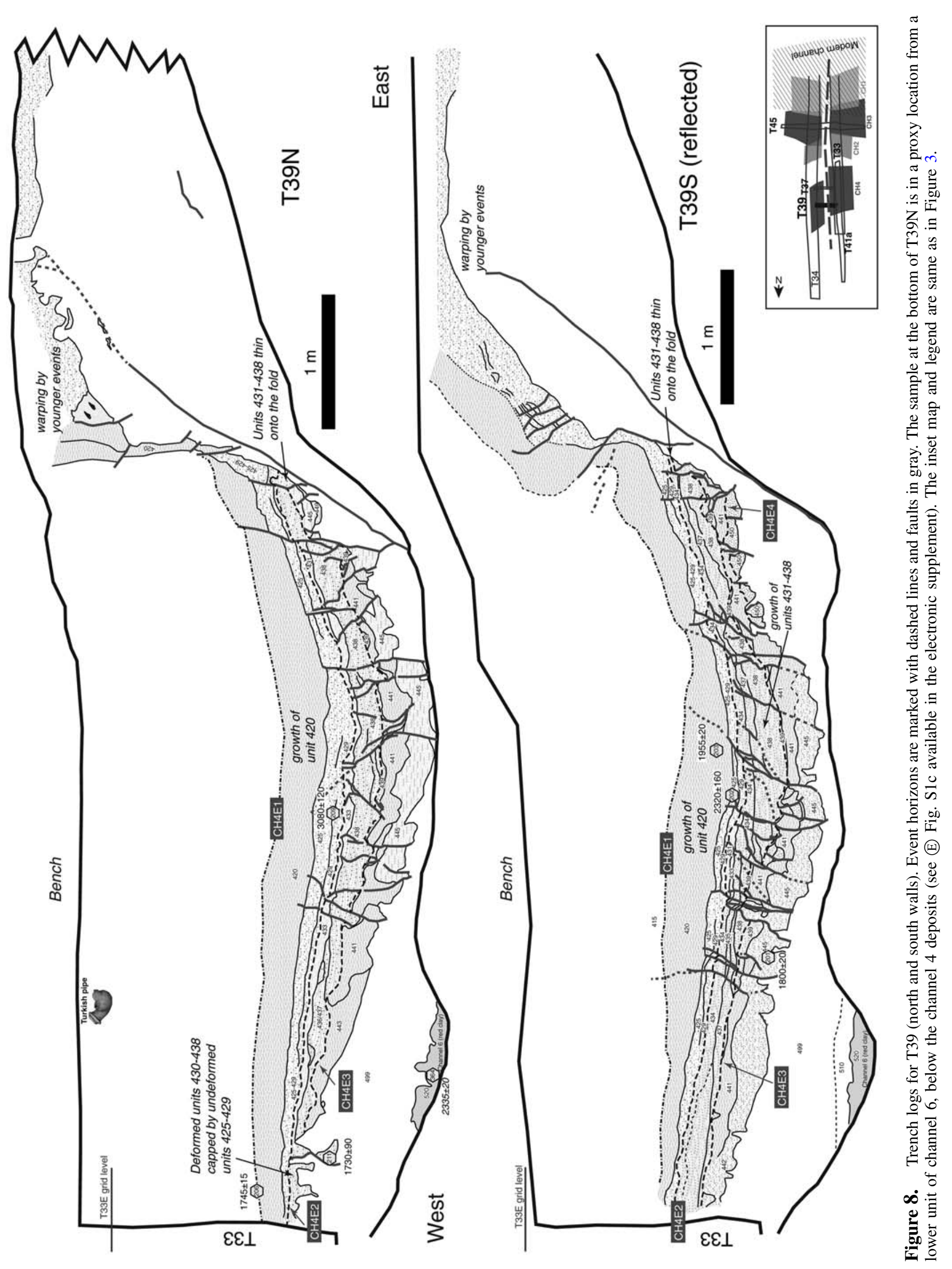


significant down-to-the-west component of vertical motion, although a lesser down-to-the-east component is observed on the east side of the pressure ridge. Thus, from the exposures in T33, T37, and T37, the stratigraphy is most consistent with the overall model of left-lateral displacement across a narrow pressure ridge with central uplift and an overall west-side-down long-term component of vertical motion. It is within this context that we discuss the evidence for multiple surface ruptures in the channel 4 complex.

The overall chronology of the channel 4 complex is provided by the radiocarbon dating of 24 samples from these three trenches. As with all detrital charcoal, some samples yielded ages that are too old relative to other sample ages, reflecting either the burning of older wood or their residence within the system for an extended period of time. Nevertheless, 10 of the samples yielded ages in stratigraphic order, assuming the youngest dates from each strata are closest to the actual depositional age of a stratum, and we use these dates to construct a chronologic model to constrain the event ages. From these dates, channel 4 ranges in age from at least as early as the first century C.E. up through the fourth century C.E., although the lowermost sandy gravel of channel 4 remains undated and may extend back into the latest part of the third millennium, as its age is only constrained by one sample (sample 364, see Table 2) taken from an older channel below channel 4 (E) Fig. S1c available in the electronic supplement).

Evidence for the oldest of the interpreted events, CH4-E6, is captured in the basal channel 4 deposits exposed in trench T37 (Figs. 6, (E) S1d-e available in the electronic supplement). Ruptures are indicated by both upward termination of individual faults and folding, with angular unconformities identified that resulted from the folding events. Deposition of growth strata and possibly a colluvial wedge, along with fissures capped by undisturbed strata, support the interpretation of an event at this horizon. In the north wall of T37, units 490, 492, and 493 comprise a sandy gravel deposit that is strongly disrupted by many small faults and probable liquefaction. Units 491 and 494 are silty-clay layers and are strongly deformed at the bottom of the trench. This section is folded up onto the pressure ridge and generally maintains a similar thickness, indicating deformation took place after the deposition of unit 490 . Units 480 through 489 thin onto the scarp/pressure ridge, indicating deposition after the deformation associated with event CH4-E6, and unit 489 caps many small faults that disrupt strata up through unit 490. Furthermore, units 480-489 thicken across the older folded strata, indicating postevent growth. Similar relationships are observed on the south wall of the T37, with units 480-489 capping many small faults and thinning onto the pressure ridge. These relationships argue that event CH4-E6 produced significant deformation at this site and was likely a relatively large earthquake.

Event CH4-E5 is interpreted from many small faults that break to the top of unit 480 and are capped by units $450-469$. On the south wall of T37, stratigraphic growth is seen where units 450-460 thicken in the axis of a small syncline in the area of the greatest change in bedding dip, and these strata thin onto the fold scarp of the pressure ridge, thereby also supporting growth of the primary structure. However, the amount of deformation appears relatively minor when compared with that in event CH4-E6, so we interpret this as a smaller event.

Evidence for event CH4-E4 is observed in both trenches $\mathrm{T} 37$ and T33, and there is also evidence at the bottom of the south wall of T39. In T37, several small faults rupture up through units 450-469 and are capped by unbroken strata of units 440-449, and this relationship is consistent on both walls. Included within these many faults is a significant fissure exposed on the south wall that is either capped or filled by unit 449 . Further, units $440-449$ thin and pinch out onto the fold scarp indicating growth of the fold/pressure ridge after deposition of unit 450. In trench T33, minor faults displace strata up through unit 450 and appear capped by unit 440-449, which appeared as a single stratum in this exposure (Figs. 7, (E) S1f available in the electronic supplement). Altogether, the evidence is strong for the occurrence of an event between deposition of units 449 and 450, although the amount of deformation appears less than that associated with event CH4-E6.

Evidence for the youngest three interpreted events in the channel 4 complex is observed primarily in trench T39 (Figs. 8, (E) S1g-h available in the electronic supplement), although evidence for event CH4-E3 is also seen in T33. In fact, it is in T33 where stratigraphic separation can be demonstrated between events CH4-E4 and CH4-E3, with CH4-E4 breaking up through unit 450 and capped by the sandy-clay strata of units 440-449, and CH4-E3 breaking through 440-449 and into the bottom-most unit (439) of the gravelly sand package of units 430-439. The gravelly sand fills down into the fault, indicating the event occurred during deposition of this channel deposit and was later capped by similar gravelly sand units. The same deposit (units 440449) is identified in trench T37, where it is above the event horizon for CH4-E4, and it is exposed in trench T39, where CH4-E3 is interpreted at precisely the same level.

On both walls of T39, many fault strands break into the 439-449 units package, with the sand and gravel filling into each fault. Many of the faults re-ruptured in subsequent events, but many did not. Many of the faults are capped by strata of units 430-438, which are similar to unit 439. These units also thicken in a shallow synclinal form that we interpret as produced by event CH4-E3. Finally, strata of units 430-438 thin onto and terminate against the fold scarp of the pressure ridge.

One interesting aspect of the T39 exposure is that units 440-449 also appear to thicken into the same synclinal trough as the overlying strata of units 430-439. As these are the basal channel deposits exposed in this trench, this observation suggests that units 440-449 filled a synclinal depression adjacent to the linear pressure ridge, consistent with an 


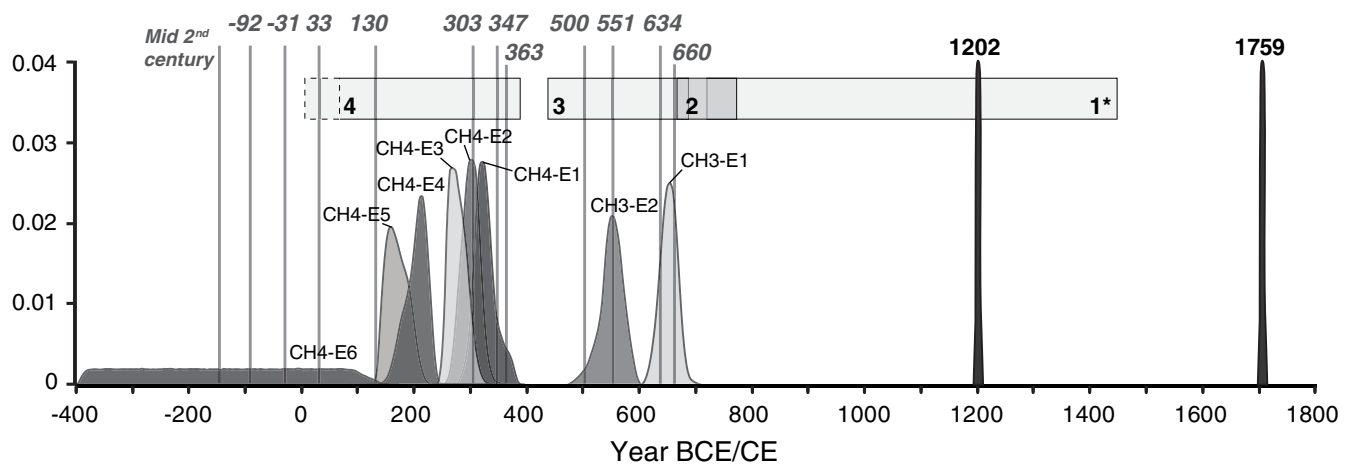

Figure 9. Probability density functions for all paleoseismic events, based on the OxCal modeling. Historically known earthquakes are marked by gray lines. The age extent of each channel is marked by rectangles. There is an age uncertainty as to the age of the oldest units in channel 4 (units 490-499) marked by a dashed rectangle. Channel 1 refers to the channel complex studied by Marco et al. (2005).

event immediately prior to their deposition. This is stratigraphically consistent with event CH4-E4.

Evidence for event CH4-E2 is weaker than that of some events, with several small faults terminating at the top of unit 430 , and capped by unit 429 . On the north wall of T39, units 425-429 thicken in the synclinal trough, arguing for fold growth after unit 430. Also on the north wall, there are several small faults filled with sediments of units 430-438 (undetermined due to mixing?) that are capped by unbroken strata of unit 429. Collectively, we argue for an event horizon between units 429 and 430 that exhibits relatively minor overall deformation.

Finally, event CH4-E1 breaks up through unit 425 and into unit 420 on several faults on both walls of T39. There is no clear event horizon because the strata are relatively massive, but there is a thickening of unit 420 in the synclinal trough, arguing that the deformation is synchronous with the deposition of unit 420 , which we consider as the approximate event horizon.

It should be noted that each of the identified events is based on local evidence within the strata of channel 4 , whereas there has clearly been substantial additional deformation of the section as a result of more recent ruptures. This is seen by the substantial warping and displacement of units 425 and all overlying strata, where preserved. In the capping lake clay, shears may be evident above recognizable faults that penetrate the base of the clay but are then obscured and completely transparent in the massive clay itself.

The ages of individual rupture events in the channel 4 complex are best constrained by 10 radiocarbon dates from samples taken from within the channel 4 deposits, age constraints from the younger channel 3 complex, and from a single charcoal sample from underneath the channel 4 complex. The lack of good age control on the basal channel 4 deposits in trench T37 limits our ability to precisely date event CH4E6, although additional historical information allows some additional constraints.

Using the OxCal model developed for all of channels 3 and 4 and adding the additional date from underneath channel 4 , we calculate the probability distributions for each event from CH4-E6 through CH4-E1 (Fig. 5). Event CH4-E6 is the least well constrained because we have no dates from the basal faulted deposit, and therefore the age is only constrained by a sample that is likely considerably older, as it predates the channel 4 complex altogether. The probability distribution exhibits a boxcar distribution that places the age of the event between 400 B.C.E. and 100 C.E. However, as the basal deposits are clearly associated with channel 4 and are probably not substantially older than other basal deposits of channel 4 , we assume the base of channel 4 is on the young side of this distribution, likely making this event fall within the range of the first century B.C.E. to first century C.E.

Events CH4-E2 through CH4-E5 all have direct radiocarbon control, although the strata between events CH4-E3 and CH4-E4 are only dated by a single sample. Nevertheless, the calculated ages for the events are as follows: event CH4E5 dates between 137 and 206 C.E. with a peak probability at $169 \pm 38$ C.E.; event CH4-E4 dates between 165 and 236 C.E., with a peak probability at $204 \pm 34$ C.E.; event CH4-E3 dates between 250 and 310 C.E., with a peak distribution at $277 \pm 30$ C.E.; and event CH4-E2 dates between 269 and 329 C.E., with a peak probability at $299 \pm 30$ C.E.

Event CH4-E1 occurred during the deposition of unit 420 , and this unit has only a single date that provides some age constraint. The sample was taken from near the upper boundary of this unit, so we assume the sample age postdates the timing of event $\mathrm{CH} 4-\mathrm{E} 1$ because unit 420 appears to thicken in the synclinal axis, which suggests the event occurred early in the deposition of unit 420. With this assumption in place, we calculate the age of event CH4E1 to be in the range of 294-369 C.E., with a peak probability at $326 \pm$ 36 C.E. If the date actually is in the faulted part of unit 420 , then the date of event CH4-E1 may be as much as a century younger. However, it cannot be as young as the basal deposit of channel 3 unless both channels were active at the same time, which we consider unlikely.

\section{Discussion}

We present evidence for eight events that pre-date the 1202 and 1759 C.E. earthquakes identified by Marco et al. 
Table 3

Modeled Earthquake Dates and Possible Historical Earthquakes from the Same Period

\begin{tabular}{|c|c|c|c|}
\hline Event & Modeled Age & Historical & Description \\
\hline $\mathrm{CH} 3-\mathrm{E} 1$ & 619-684 C.E. & 634, 660 C.E. & $\begin{array}{l}660 \text { C.E.: two events, one in the Jordan valley, the other in Jericho } \\
634 \text { C.E.: earthquake accompanied by } 30 \text { days of shaking, comet, } \\
\text { and darkness; damage in Jerusalem and Beit-She'an }\end{array}$ \\
\hline CH3-E2 & 505-593 C.E. & 500, 551 C.E. & $\begin{array}{l}551 \text { C.E.: damage in Lebanon and Syria, epicenter probably off-shore } \\
\text { Lebanon (Elias et al., 2007) }\end{array}$ \\
\hline CH4-E1 & 294-369 C.E. & 303, 347, 363 C.E. & $\begin{array}{l}\text { 500/502 C.E.: destruction in Acre (northern Israel), Tyre, Sidon (Lebanon) } \\
363 \text { C.E.: extensive damage from Paneas (Banyas) in the north to } \\
\text { Petra in the south (Kagan et al. [2011] consider this to be two } \\
\text { separate earthquakes with damage in geographically } \\
\text { separate regions.) }\end{array}$ \\
\hline $\mathrm{CH} 4-\mathrm{E} 2$ & 269-329 C.E. & 303, 347 C.E. & 347 C.E.: destruction at Beirut, Syrian coast; possibly off-coast earthquake. \\
\hline CH4-E3 & 250-310 C.E. & 303 C.E. & $\begin{array}{l}303 \text { C.E.: destruction at Tyre, Sidon, Gush Halav; damage to Khirbet } \\
\text { Shema, Nabratein (near Safed), Jerusalem; tsunami in Caesarea }\end{array}$ \\
\hline $\mathrm{CH} 4-\mathrm{E} 4$ & 165-236 C.E. & None & \\
\hline CH4-E6 & 392 B.C.E.-91 C.E. & $\begin{array}{l}\text { Mid-second century } \\
\text { B.C.E., } 92 \text { B.C.E. } \\
31 \text { B.C.E., } 33 \text { C.E. }\end{array}$ & $\begin{array}{l}33 \text { C.E.: earthquake in Jerusalem, mentioned in the New Testament } \\
31 \text { B.C.E.: earthquake during Herod's time; } 30,000 \text { men killed } \\
\text { according to Flavius } \\
92 \text { B.C.E.: tsunami in the eastern Mediterranean; mentioned in } \\
\text { Jewish texts; no clear source location } \\
\text { Mid-second century B.C.E.: tsunami between Antioch and Acre; } \\
\text { no clear source location }\end{array}$ \\
\hline
\end{tabular}

Sources for historical earthquakes include Amiran et al. (1994), Guidoboni (1994), and Ambraseys (2009).

(2005). The youngest of them, event CH3-E1, dates to the mid-seventh century C.E. Marco et al. mention 685 C.E. as an upper bound date of the offset units that recorded $2.7 \mathrm{~m}$ offset (Marco's CH2, CH3). However, they do have younger dates from the same unit, so, assuming the older dates are residuals, this upper bound is pushed to the beginning of the eleventh century C.E. There is no lower age constraint because they did not date samples from below those units. Based on the detrital carbon ages from the channel units discussed above, we consider the period between the first and eighth centuries C.E. to be well covered, with the exception of the first half of the fifth century C.E. (Fig. 9). The nearly continuous sedimentary record for that period recorded eight earthquakes, and it is reasonable to assume this is a complete record of surface-rupturing earthquakes on the JGF for that period. There may be a missing record for the period between the deposition of channel 2 and channel 1 . The historical catalogs mention a destructive earthquake and landslide in Tiberias, on the west coast of the lake, in 850-854 C.E. We do not have channel deposits with ages that cover the period and therefore cannot determine whether this earthquake ruptured at the Beteiha site.

\section{Earthquake Record in View of Historical and Other Records}

Table 3 and Figure 9 summarize the event ages obtained from the OxCal model and compare them with known historical earthquakes from that period. The uncertainty regarding the age of the oldest event in channel 4 makes finding the equivalent historical earthquake difficult; however, if indeed the lower part of channel 4 is closer in age to the rest of the channel units, then it is reasonable to assume the event occurred around the turn of the millennium and could correlate with the 31 B.C.E. earthquake of Herod's time. Earlier candidate events include 92 B.C.E. and an earthquake in midsecond century B.C.E., but the location of those events is not clear (Table 3).

In the historical records there is no mention of any earthquake anywhere along the DST between 130-303 C.E., and the same is true for the Dead Sea cores (Kagan et al., 2011). Channel 4 units span this period of time, and in them we detected evidence for 3-4 events with model ages that overlap this time period (events CH4-E5 through E2), and one of those events fall completely within the supposed seismic quiescence period (CH4-E4). It is well known that the historical earthquake record is incomplete in general, and specifically for that time period (Late Roman) during which the Roman empire was in decline, and the main historical texts describing this period are compilations written by historians who lived during later periods. It is therefore likely that a moderate earthquake could occur and not be recorded in either historical sources or by the Dead Sea seismites, yet cause sediment disruption and surface rupture along the JGF. An earthquake of magnitude $\sim 6-6.5$ would rupture the surface at Bet-Zayda Valley and be detectable in trenches (e.g., LiuZeng et al., 2007) but not by Dead Sea seismites that are more than $100 \mathrm{~km}$ away (figure 9 of Kagan et al., 2011).

In the historical earthquakes catalog for the time period equivalent to the paleoseismic record, there are a few 


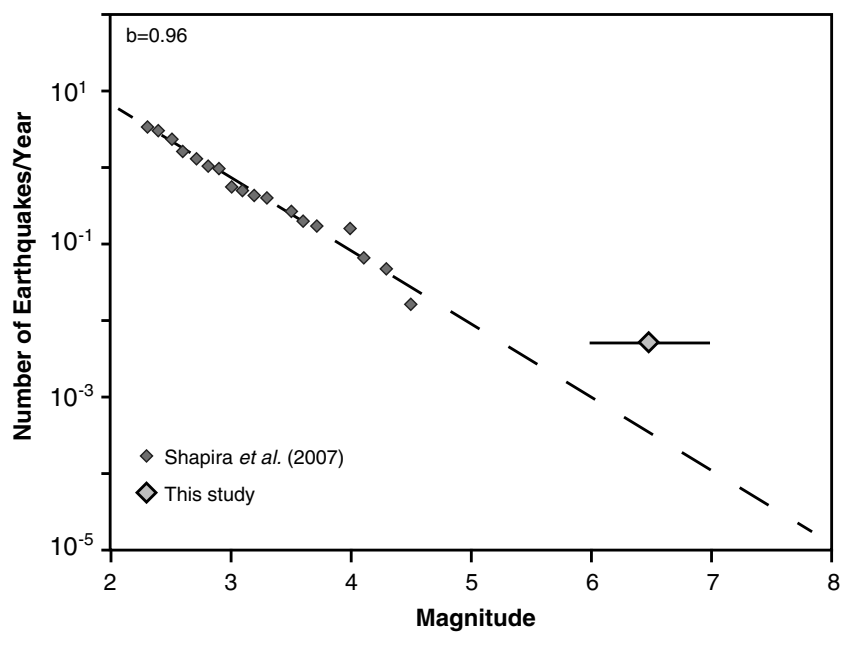

Figure 10. Earthquake cumulative frequency (in number of earthquakes of equal or larger magnitude per year) versus magnitude for the Sea of Galilee and Hula Valley region, from modern seismicity (Shapira et al., 2007). The large diamond represents the events found in this study, assuming they all were at least $M_{\mathrm{w}} 6.5$.

earthquakes with evidence of damage that are not centered along the JGF or in northern Israel. For example, the 551 C.E. earthquake is thought to have ruptured offshore Lebanon, on the Mount Lebanon Thrust (Elias et al., 2007). Yet we must consider the possibility that the rupture extended to the south, along the Roum fault (Darawcheh et al., 2000) and onto the JGF (Wechsler et al., 2009) or that what is described as one earthquake in the historical record was actually a series of events, one triggering the other, that were amalgamated in the historical record. Some of the ruptures recorded in the paleoseismic record could be either the rupture tip of an earthquake that originated on another fault segment (north or south of the site) or a triggered event on the JGF that would not merit its own historical mention. An example for an earthquake that originated to the north is the 1202 C.E. event, which was centered on the Yammouneh fault but also ruptured all the way south through the JGF and maybe even farther south.

Other known historical earthquakes that were not centered on the JGF, but which may have either ruptured to the Sea of Galilee or triggered slip or an aftershock include earthquakes in 33, 130, 303, 347, 363, 500, 634, and 660 C.E. (Fig. 9, Table 3). Considering that all detrital charcoal ages are maximum ages for the host deposit because the date reflects the growth and death of the original wood rather than its burning or deposition, some of the events we identify and date in the channel stratigraphy may have a slight bias toward an older age, in which case most may actually be represented in the historical record. In any case, a slight shift in event ages does not affect our overall conclusion that there was a cluster of earthquakes that produced surface rupture along the JGF during the first millennia C.E., followed by a relative dearth of events in the second millennia C.E.

\section{Fault Behavior during the Last 2000 Years}

In the past 2000 years, we observe evidence for a total of 10 surface-rupturing earthquakes, of which seven or eight events occurred in the first millennium, compared to just two in the second millennium C.E. This demonstrates that the fault is not behaving in a periodic fashion on a scale of 2000 years and several earthquake cycles. Based on model ages and taking into account the uncertainties in modeled event ages, the overall earthquake occurrence interval for the last 2 millennia is $199 \pm 111$ years. When computed separately for each millennium, it is $553 \pm 32$ years for the second millennium and $80 \pm 106$ for the first millennium (excluding CH4-E6, the oldest event, for which the lower age constraint is poor). These recurrence values do not account for differing earthquake magnitudes and demonstrate how the recurrence interval can be a misleading quantity when trying to estimate the regional earthquake risk.

The past 1000-year period appears deficient in strain release, starting from the Lebanese restraining bend (Däeron et al., 2007), through the Jordan Valley (Ferry et al., 2007) and southward to the Gulf of Aqaba (Klinger et al., 2000). Thus, in terms of moment release, most of the plate boundary has remained locked and has been accumulating elastic strain, as supported by recent GPS data (Sadeh et al., 2012).

In contrast, the preceding 1200 years or so experienced a spate of earthquake activity, with large events along the Jordan Valley segment alone in 31 B.C.E., 363, 749, and 1033 C.E. (Guidoboni, 1994; Marco et al., 2003; Guidoboni and Comastri, 2005). Thus, the recurrence interval appears to vary by a factor of two to four during the historical period in the Jordan Valley, as well as at our site.

Studies of the recent seismic activity and frequencymagnitude relations in northern Israel suggest an estimated return period of 340 years for $\mathbf{M}>6$ and 4500 for $\mathbf{M}>7$ earthquakes using the Gutenberg-Richter (GR) relation, with a corresponding slip rate of $1.9 \mathrm{~mm} / \mathrm{yr}$ (Shapira and Hofstetter, 2002). Hough and Avni (2009) combined available instrumental and historical earthquake data for the region and surmised that the GR distribution is valid for the DST. We compare the earthquake occurrence rate for the Sea of Galilee and Hula area from modern seismic records (Shapira et al., 2007) to the recurrence rate of large earthquakes based on paleoseismic records (Fig. 10), assuming a magnitude equal to or larger than $6.5 \pm 0.5$ for the surface-rupturing events. The result does not follow the GR distribution; rather it is similar to the characteristic earthquake distribution, with a discrepancy in the rate of small-magnitude earthquakes, as also observed on other faults (Hecker et al., 2013). This discrepancy can be explained if we consider that the instrumental record is missing both moderate-to-large events and their aftershocks, which can decrease the $a$-value of the GR distribution by a factor of 2 (Page et al., 2008).

A possible explanation for the earthquake behavior observed at the Beteiha site is that it is affected by its southern neighboring segments, as there is the possibility that earth- 
quakes nucleating in the Jordan Valley can rupture through the Galilee stepover to the south of Bet-Zayda (Fig. 2). Ruptures originating from the north are also likely, as demonstrated by the 1202 earthquake (Marco et al., 2005). Another possibility is that large earthquakes on the Jordan Valley, Yammounneh, Roum, or Sergaya segments may trigger smaller aftershock events on the Jordan Gorge segment, in which case the historical record may tend to amalgamate any evidence for multiple, closely timed events into one large event.

The temporal variations in earthquake production may conform to a slip-predictable fault behavior, but more slip per event data are needed to determine the validity of the slip-predictable model for the JGF. A scenario of unzipping of the whole DST system, similar to the behavior of the North Anatolian fault (Stein et al., 1997), can account for periods of lesser activity. The nonperiodic behavior of the DST over the millennial timescale makes it more difficult to meaningfully predict the probability for a large earthquake soon. It may be that the 1995 M 7.3 Aqaba earthquake is the first in a sequence of future earthquakes that will soon be followed by several large earthquakes from south to north. It is also possible that a new cluster of moderate earthquakes was initiated with the October 1759 earthquake on the JGF, in which case we might expect several such events prior to a repeat of a 1202-type very large rupture. Regardless, in terms of moment release, most of the fault has remained locked and is accumulating elastic strain. Therefore, it is imperative to prepare for a large earthquake on the DST, which will occur sooner or later.

\section{Data and Resources}

All data used in this paper came from the published sources listed in the references.

\section{Acknowledgments}

The authors would like to thank all of the people who helped during the trenching campaigns: J. Barrett Salisbury, Katie Farrington, Jakub Stembek, Mike Buga, Esteban Bowles-Martinez, Eitan Philip, and, last but not least, Ronen Gersman. This project was funded by the National Science Foundation, Grant EAR-1019871 to T. Rockwell. N. Wechsler was partially supported by a City of Paris grant. Y. Klinger was partially supported by the Libris project (ANR-09-RISK-006). P. Štěpančíková was partially supported by the Czech Science Foundation (Project Number P210/12/0573). The paper benefited from the comments of Olaf Zielke and an anonymous reviewer.

\section{References}

Ambraseys, N. N. (2009). Earthquakes in the Mediterranean and Middle East: A Multidisciplinary Study of Seismicity up to 1900, Cambridge University Press, New York, 947 pp.

Ambraseys, N. N., and M. Barazangi (1989). The 1759 earthquake in the Bekaa valley: Implications for earthquake hazard assessment in the eastern Mediterranean region, J. Geophys. Res. 94, 4007-4013.

Ambraseys, N. N., and C. P. Melville (1988). An analysis of the eastern Mediterranean earthquake of 20 May 1202, in Historical Seismograms and Earthquakes of the World, W. K. H. Lee, H. Meyers, and K. Shimazaki (Editors), Academic Press, San Diego, California, 181-200.

Amiran, D. H. K., E. Arieh, and T. Turcotte (1994). Earthquakes in Israel and adjacent areas: Macroseismic observations since 100 B.C.E., Isr. Explor. J. 44, 260-305.

Bakun, W. H., and T. V. McEvilly (1984). Recurrence models and Parkfield, California, earthquakes, J. Geophys. Res. 89, 3051-3058.

Ben-Gai, Y. (2010). Subsurface geology of the southern Lake Kinneret (Sea of Galilee), Dead Sea transform-Evidence from seismic reflection data, Isr. J. Earth Sci. 58, 163-175.

Bronk-Ramsey, C. (2009). Bayesian analysis of radiocarbon dates, Radiocarbon 51, 337-360.

Däeron, M., Y. Klinger, P. Tapponnier, A. Elias, E. Jacques, and A. Sursock (2005). Sources of the large AD 1202 and 1759 Near East earthquakes, Geology 33, 529-532.

Däeron, M., Y. Klinger, P. Tapponnier, A. Elias, E. Jacques, and A. Sursock (2007). 12,000-year-long record of 10 to 13 paleoearthquakes on the Yammouneh fault, Levant fault system, Lebanon, Bull. Seismol. Soc. Am. 97, 749-771.

Darawcheh, R., M. R. Sbeinati, C. Margottini, and S. Paolini (2000). The 9 July $551 \mathrm{AD}$ Beirut earthquake, eastern Mediterranean region, $J$. Earthq. Eng. 4, 403-414.

Elias, A., P. Tapponnier, S. C. Singh, G. C. P. King, A. Briais, M. Däeron, H. Carton, A. Sursock, E. Jaques, R. Jomaa, and Y. Klinger (2007). Active thrusting offshore Mount Lebanon: Source of the tsunamigenic AD 551 Beirut-Tripoli earthquake, Geology 35, 755-758.

Ellenblum, R., S. Marco, A. Agnon, T. Rockwell, and A. Boas (1998). Crusader castle torn apart by earthquake at dawn, 20 May 1202, Geology 26, 303-306.

Ellenblum, R., S. Marco, R. Kool, U. Davidovitch, R. Porat, and A. Agnon (2013). Archaeological reconstruction of a plate boundary: Slip events along the Jordan-Dead Sea fault since Iron Age IIa, Earth Planet. Sci. Lett. (in press).

Ferry, M., M. Meghraoui, N. Abou Karaki, M. Al-Taj, H. Amoush, S. AlDhaisat, and M. Barjous (2007). A 48-kyr-long slip rate history for the Jordan Valley segment of the Dead Sea fault, Earth Planet. Sci. Lett. 260, 394-406.

Ferry, M., M. Meghraoui, N. Abou Karaki, M. Al-Taj, and L. Khalil (2011). Episodic behavior of the Jordan Valley section of the Dead Sea fault inferred from a 14-ka-long integrated catalog of large earthquakes, Bull. Seismol. Soc. Am. 101, 926-927.

Field, E. H., and M. T. Page (2011). Estimating earthquake-rupture rates on a fault or fault system, Bull. Seismol. Soc. Am. 101, 79-92.

Freund, R., I. Zak, and Z. Garfunkel (1968). Age and rate of the sinistral movement along the Dead Sea rift, Nature 220, 253-255.

Fumal, T. E., R. J. Weldon, G. P. Biasi, T. E. Dawson, G. G. Seitz, W. T. Frost, and D. P. Schwartz (2002). Evidence for large earthquakes on the San Andreas fault at the Wrightwood, California, paleoseismic site: AD 500 to present, Bull. Seismol. Soc. Am. 92, 2726-2760.

Garfunkel, Z. (1981). Internal structure of the Dead Sea leaky transform (rift) in relation to plate kinematics, Tectonophysics 80, 81-108.

Garfunkel, Z. (1989). Regional deformation by block translation and rotation, in Paleomagnetic Rotations and Continental Deformation, C. Kissel and C. Laj (Editors), Kluwer Academic Publishers, Dordrecht, The Netherlands, 181-208.

Gomez, F., M. Meghraoui, A. N. Darkal, F. Hijazi, M. Mouty, Y. Suleiman, R. Sbeinati, R. Darawcheh, R. Al-Ghazzi, and M. Barazangi (2003). Holocene faulting and earthquake recurrence along the Serghaya branch of the Dead Sea fault system in Syria and Lebanon, Geophys. J. Int. 153, 658-674 (Correction, Geophys. J. Int., 155, 749-750, 2003).

Guidoboni, E. (1994). Catalogue of Ancient Earthquakes in the Mediterranean Area up to the 10th Century, Istituto Nazionale di Geofisica, Rome, Italy.

Guidoboni, E., and A. Comastri (2005). Catalogue of Earthquakes and Tsunamis in the Mediterranean Area from the 11th to the 15th Century, Istituto Nazionale di Geofisica, Bologna, Italy, 1037 pp. 
Hazan, N., M. Stein, A. Agnon, S. Marco, D. Nadel, J. F. W. Negendank, M. J. Schwab, and D. Neev (2005). The late quaternary limnological history of Lake Kinneret (Sea of Galilee), Isr. Q. Res. 63, 60-77.

Hecker, S., N. Abrahamson, and K. Wooddell (2013). Variability of displacement at a point: Implications for earthquake-size distribution and rupture hazard on faults, Bull. Seismol. Soc. Am. 103, 651-674.

Heimann, A. (1990). The development of the Dead Sea rift and its margins in the northern Israel during the Pliocene and the Pleistocene, Golan Res. Inst. and Geol. Surv. Isr. Rept., GSI/28/90 (in Hebrew, English abstract).

Heimann, A., and H. Ron (1993). Geometric changes of plate boundaries along part of the northern Dead Sea transform: Geochronologic and paleomagnetic evidence, Tectonics 12, 477-491.

Heimann, A., E. Zilberman, R. Amit, and U. Frieslander (2009). Northward migration of the southern diagonal fault of the Hula pull-apart basin, Dead Sea transform, northern Israel, Tectonophysics 476, no. 3, 496511.

Hough, S. E., and R. Avni (2009). The 1170 and 1202 CE Dead Sea rift earthquakes and long-term magnitude distribution of the Dead Sea fault zone, Isr. J. Earth Sci. 58, 295-308.

Kagan, E., M. Stein, A. Agnon, and F. Neumann (2011). Intrabasin paleoearthquake and quiescence correlation of the late Holocene Dead Sea, J. Geophys. Res. 116, no. B04311, doi: 10.1029/2010JB007452.

King, G., R. Stein, and J. Lin (1994). Static stress changes and the triggering of earthquakes, Bull. Seismol. Soc. Am. 84, 935-953.

Klinger, Y., J. P. Avouac, L. Dorbath, N. Abou Karaki, and N. Tisnerat (2000). Seismic behaviour of the Dead Sea fault along Araba Valley, Jordan, Geophys. J. Int. 142, 769-782.

Klinger, Y., M. Etchebes, P. Tapponnier, and C. Narteau (2011). Characteristic slip for five great earthquakes along the Fuyun fault in China, Nat. Geosci. 4, 389-392.

Le Beon, M., Y. Klinger, A. Q. Amrat, A. Agnon, L. Dorbath, G. Baer, J.-C. Ruegg, O. Charade, and O. Mayyas (2008). Slip rate and locking depth from GPS profiles across the southern Dead Sea Transform, J. Geophys. Res. 113, B11403, doi: 10.1029/2007JB005280.

Liu-Zeng, J., Y. Klinger, X. Xu, C. Lasserre, G. Chen, W. Chen, P. Tapponnier, and B. Zhang (2007). Millennial recurrence of large earthquakes on the Haiyuan fault near Songshan, Gansu Province, China, Bull. Seismol. Soc. Am. 97, 14-34.

Marco, S., M. Hartal, N. Hazan, L. Lev, and M. Stein (2003). Archeology, history, and geology of the A.D. 749 earthquake, Dead Sea transform, Geology 31, 665-668.

Marco, S., T. K. Rockwell, A. Heimann, U. Frieslander, and A. Agnon (2005). Late Holocene activity of the Dead Sea transforrn revealed in 3D palaeoseismic trenches on the Jordan Gorge segment, Earth Planet. Sci. Lett. 234, 189-205.

Marco, S., M. Stein, A. Agnon, and H. Ron (1996). Long term earthquake clustering: A 50,000 year paleoseismic record in the Dead Sea graben, J. Geophys. Res. 101, 6179-6192.

Meiler, M., M. Reshef, and H. Shulman (2011). Seismic depth-domain stratigraphic classification of the Golan Heights, central Dead Sea Fault, Tectonophysics 510, nos. 3-4, 354-369.

Migowski, C., A. Agnon, R. Bookman, J. F. W. Negendank, and M. Stein (2004). Recurrence pattern of Holocene earthquakes along the Dead Sea transform revealed by varve-counting and radiocarbon dating of lacustrine sediments, Earth Planet. Sci. Lett. 222, 301-314.

Nemer, T., and M. Meghraoui (2006). Evidence of coseismic ruptures along the Roum fault (Lebanon): A possible source for the AD 1837 earthquake, J. Struct. Geol. 28, 1483-1495.

Ninis, D., T. A. Little, R. J. Van Dissen, N. J. Litchfield, E. G. Smith, N. Wang, U. Rieser, and C. M. Henderson (2013). Slip rate on the Wellington fault, New Zealand, during the late Quaternary: Evidence for variable slip during the Holocene, Bull. Seismol. Soc. Am. 103, 559-579.

Page, M., K. Felzer, R. Weldon, and G. Biasi (2008). The magnitudefrequency distribution on the southern San Andreas fault follows the Gutenberg-Richter distribution, in Eos Trans. AGU 1, 6 (Fall Meeting Abstracts)
Quennell, A. M. (1956). Tectonics of the Dead Sea rift, in Congreso Geologico Internacional, 20th sesion, Asociacion de Servicios Geologicos Africanos, Mexico City, Mexico, 385-405.

Reid, H. F. (1910). The Mechanics of the Earthquake, Carnegie Institute, Washington, D.C., 192 pp.

Reilinger, R., and S. McClusky (2011). Nubia-Arabia-Eurasia plate motions and the dynamics of Mediterranean and Middle East tectonics, Geophys. J. Int. 186, 971-979.

Reilinger, R., S. McClusky, P. Vernant, S. Lawrence, S. Ergintav, R. Cakmak, H. Ozener, F. Kadirov, I. Guliev, and R. Stepanyan (2006). GPS constraints on continental deformation in the Africa-Arabia-Eurasia continental collision zone and implications for the dynamics of plate interactions, J. Geophys. Res. 111, doi: 10.1029/2005JB004051.

Reimer, P. J., M. G. Baillie, E. Bard, A. Bayliss, J. W. Beck, P. G. Blackwell, C. B. Ramsey, C. E. Buck, G. S. Burr, and R. L. Edwards (2009). IntCa109 and Marine09 radiocarbon age calibration curves, 0-50,000 years cal BP, Radiocarbon 51, no. 4, 1111-1150.

Rockwell, T. K. (2010). The non-regularity of earthquake recurrence in California: Lessons from long paleoseismic records in simple vs complex fault regions, in AGU Fall Meeting Abstracts, Vol. 1, 04.

Rockwell, T. K., and Y. Klinger (2013). Surface rupture and slip distribution of the 1940 Imperial Valley earthquake, Imperial fault, southern California: Implications for rupture segmentation and dynamics, Bull. Seismol. Soc. Am. 103, 629-640.

Rockwell, T. K., N. Wechsler, and K. Okumura (2013). 4-D ruptures histories of major plate boundary faults: A view into long-term fault behavior and fault interaction, in 4th International INQUA Meeting on Paleoseismology, Active Tectonics and Archeoseismology (PATA), Aachen, Germany, 9-14 October 2013.

Rockwell, T. K., J. Young, G. Seitz, A. Meltzner, D. Verdugo, F. Khatib, D. Ragona, O. Altangerel, and J. West (2003). 3,000 years of groundrupturing earthquakes in the Anza seismic gap, San Jacinto fault, southern California: Time to shake it up, Seismol. Res. Lett. 74, 236-237.

Rybakov, M., L. Fleischer, and U. T. Brink (2003). The Hula Valley subsurface structure inferred from gravity data, Isr. J. Earth Sci. 52, $113-122$.

Sadeh, M., Y. Hamiel, A. Ziv, Y. Bock, P. Fang, and S. Wdowinski (2012). Crustal deformation along the Dead Sea transform and the Carmel fault inferred from 12 years of GPS measurements, J. Geophys. Res. 117, no. B08410, doi: 10.1029/2012JB009241.

Schattner, U., and R. Weinberger (2009). A mid-Pleistocene deformation transition in the Hula basin: Implications for the tectonic evolution of the Dead Sea Fault plate boundary, in EGU General Assembly Conference Abstracts, 10023.

Schwartz, D. P., and K. J. Coppersmith (1984). Fault behavior and characteristic earthquakes: Examples from the Wasatch and San Andreas fault zones, J. Geophys. Res. 89, 5681-5698.

Shapira, A., and A. Hofstetter (2002). Seismicity parameters of seismogenic zones, An updated map of peak ground accelerations for the Israel Standard, 1:500,000, Scientific Rept. GII 592.230, 1-15.

Shapira, A., R. Hofstetter, A. Abdallah, J. Dabbeek, and W. Hays (2007). Earthquake hazard assessments for building codes, Final report, Geophysical Institute of Israel, $88 \mathrm{pp}$.

Sieh, K. (1996). The repetition of large-earthquake ruptures, Proc. Natl. Acad. Sci. Unit. States Am. 93, 3764-3771.

Stein, R. S., A. Barka, and J. H. Dietrich (1997). Progressive failure on the North Anatolian fault since 1939 by earthquake stress triggering, Geophys. J. Int. 128, 594-604.

Wechsler, N., O. Katz, Y. Dray, I. Gonen, and S. Marco (2009). Estimating location and size of historical earthquake by combining archaeology and geology in Umm-El-Qanatir, Dead Sea transform, Nat. Hazards 50, 27-43.

Wechsler, N., T. K. Rockwell, Y. Klinger, A. Agnon, and S. Marco (2013). Historical and Paleo-seismicity of the Dead Sea Transform in northern Israel, International workshop on Tectonics of the Levant fault and Northern Red Sea, IPGP, Paris, France. 
Weldon, R., K. Scharer, T. Fumal, and G. Biasi (2004). Wrightwood and the earthquake cycle: What a long recurrence record tells us about how faults work, GSA Today 14, 4-10.

Wesnousky, S. G. (2008). Displacement and geometrical characteristics of earthquake surface ruptures: Issues and implications for seismichazard analysis and the process of earthquake rupture, Bull. Seismol. Soc. Am. 98, 1609-1632.

Working Group on California Earthquake Probabilities (WGCEP) (2007). The Uniform California Earthquake Rupture Forecast, Version 2 (UCERF 2).

Zielke, O., J. R. Arrowsmith, L. G. Ludwig, and S. O. Akciz (2010). Slip in the 1857 and earlier large earthquakes along the Carrizo Plain, San Andreas fault, Science 327, 1119-1122.

Department of Geophysical, Atmospheric, and Planetary Sciences

Tel Aviv University

Tel Aviv 69978, Israel

(N.W., M.K., S.M.)

Department of Geological Sciences

5500 Campanile Dr.

San Diego State University

San Diego, California 92182

(T.K.R.)
Equipe de Tectonique

Institut de Physique du Globe de Paris

1 , rue Jussieu

75238 Paris, France

(Y.K.)

Institute of Rock Structure and Mechanics

Academy of Science Czech Republic

v.v.i. V Holesovickach 41

18209 Prague 8

Czech Republic

(P.Š.)

Institute of Earth Sciences

Hebrew University of Jerusalem

91904 Jerusalem, Israel

(A.A.)
Manuscript received 21 November 2013; Published Online 27 May 2014 